Article

\title{
An Integrated Plan to Sustainably Enable the City of Riohacha (Colombia) to Cope with Increasing Urban Flooding, while Improving Its Environmental Setting
}

\author{
Andrea Nardini ${ }^{1, \dagger}$ and Marcelo Gomes Miguez ${ }^{2, *,+}$ \\ 1 Fundación CREACUA-Centro Recuperación Ecosistemas ACUÁticos, Riohacha 440001, Colombia; \\ a.nardini@cirf.org or nardiniok@gmail.com \\ 2 PEU-POLI \& COPPE, UFRJ-Universidade Federal do Rio de Janeiro, Rio de Janeiro 21941-909, Brazil \\ * Correspondence: marcelomiguez@poli.ufrj.br; Tel.: +55-21-3938-7833 \\ + These authors contributed equally to this work.
}

Academic Editor: Ken Tamminga

Received: 12 December 2015; Accepted: 13 February 2016; Published: 24 February 2016

\begin{abstract}
This paper describes the emblematic situation of a Colombian coastal town seriously threatened by flooding and presents the whole process undertaken to elaborate an integrated action plan to cope with this problem, while improving the natural and built environment. Such a plan is a product of a project, winner of a National Colombian call for climate change initiatives, which included a thorough modeling process based on the MODCEL urban flood model, an articulated participatory process including a specific structured inquiry mainly aiming at providing data suited for model calibration, a creative phase to propose candidate alternative solutions and a quite integrated evaluation exercise which supported the transparent choice of the most sustainable plan alternative. The approach and the experience can be valuable for many other cases in Colombia and around the world, particularly in developing or emerging countries where data are scarce. The added value of this paper lies in showing a whole, integrated process, well articulated, where all pieces are indispensable but simple enough to be replicated in many cases. It merges the fundamental participatory component with an equally fundamental technical-scientific component of characterization, modeling and integrated evaluation. The multiple steps of the process are illustrated with sufficient detail to allow the reader to grasp what was actually done and why, providing a practical guide for other cases.
\end{abstract}

Keywords: urban flooding; integrated urban planning; urban green adaptation; natural water retention measures; mathematical modeling and GIS algorithms; participatory process; multicriteria evaluation

\section{Riohacha: An Emblematic Developing Coastal Town in Colombia}

\subsection{Context, Strengths and Weaknesses of the Case}

Riohacha (Figure 1) is a relatively small Colombian coastal town (around 200,000 inhabitants) that is experiencing rapid economic and urban development. It has a number of environmental peculiarities that make it quite attractive to tourists: a long sea shore with nice beaches; the Rancheria river delta (and its Riito arm) with a rich mangrove forest, full of birds, aquatic life and a pleasant scenery; and a number of wetlands (called "humedales")—some totally natural, others modified or even created by humans to obtain construction material-which mark the thalweg of the urban watershed until its outlet into the Riito (Figure 2), through the historical lagoon called Laguna Salada (the locally most known wetland), which was originally an ephemeral natural hydraulic annex of the 
river and hosted several famous battles (afterward was separated from the river by the earthwork of the Riohacha-Maicao road, which left only the passage for a small artificial canal).

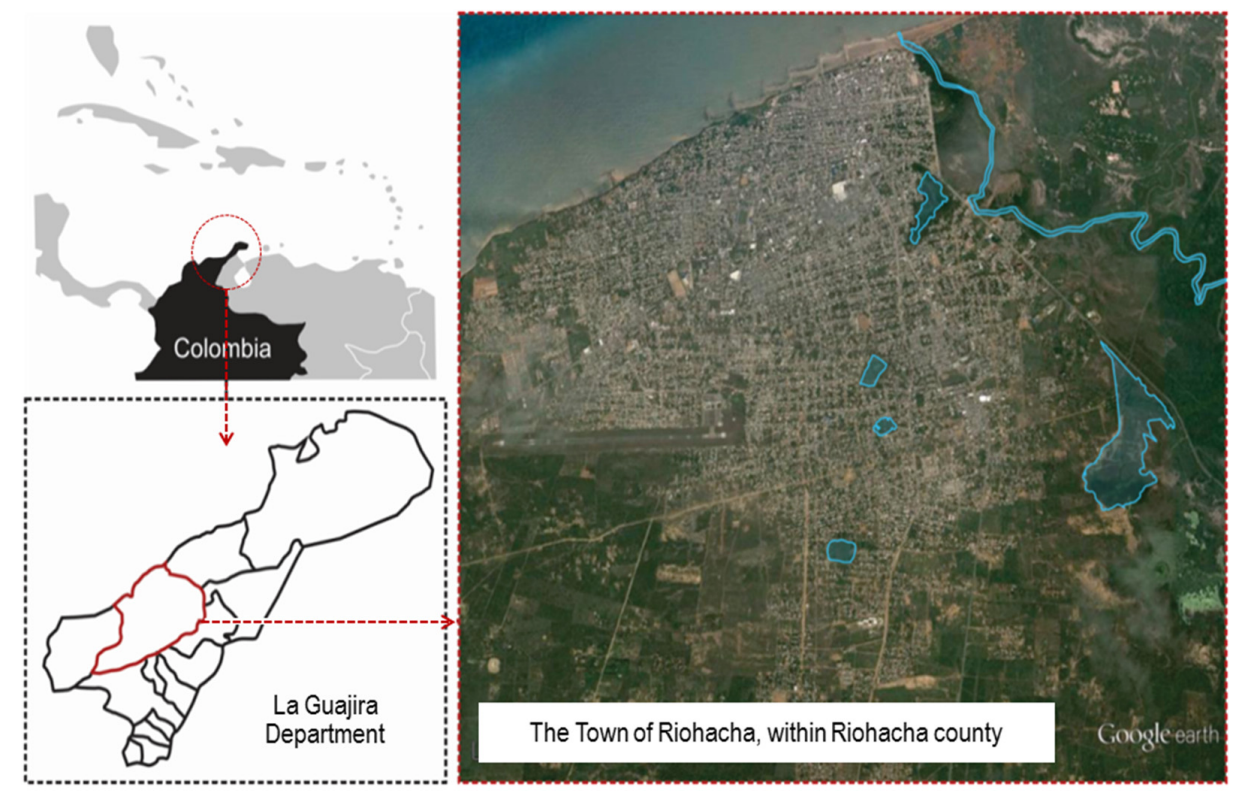

Figure 1. General location of the project area (the red bounded polygon is Riohacha County), showing also on the right the urban area of Riohacha, and highlighting its water bodies.

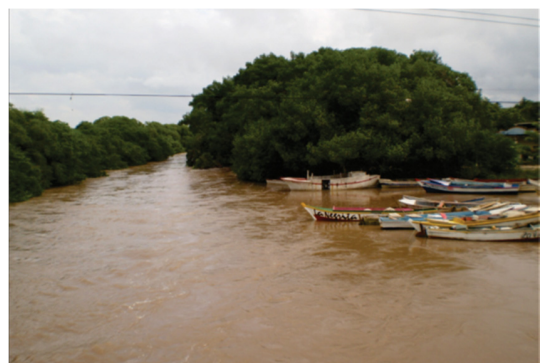

(a)

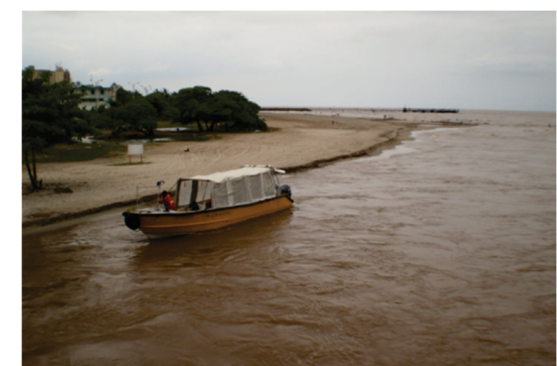

(b)

Figure 2. Riito arm of Rio Ranchería at its outlet in the city: (a) looking upstream from the last bridge and (b) looking downstream at the sea.

These wetlands are utilized for recreation by local children and are a remarkable feature of the territory. Unfortunately, they are poorly maintained and partially contaminated by wastewaters and rubbish. Besides that, such wetlands play an important role in urban floods events that threaten the town more and more.

The "ola invernal" (winter wave) - the terrible flood event that deeply affected practically the whole of Colombia in 2010-2011 associated with the la Niña phenomenon [1]—harshly impacted also Riohacha by flooding several zones and even destroying some houses, leaving thousands of people with virtually nothing but illness and despair (Figure 3). We estimated this rainfall event to have a return period of about 80 years, but flooding of parts of the town is a quite frequent phenomenon that makes life very difficult for the citizens.

\subsection{Critical Issues}

Part of the problem can certainly be attributed to the climate, but definitely the largest part of the blame rests with poor planning of the old town and the uncontrolled urban development that the town has experienced in the recent past. Apart form the increase in impervious surface, the principal natural 
thalweg of the urban watershed has been interrupted both by urbanization (houses and streets) and by a partial, progressive earth filling of the wetlands themselves and modification of their water outlets, in an attempt to conquer bit by bit new space to build (illegal) houses. The drainage system is now not able to work properly because of hydraulic constraints. Besides, retention volumes have diminished.
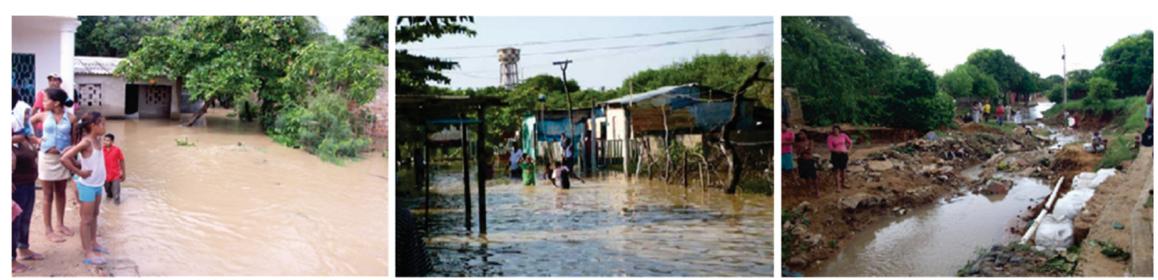

Figure 3. Some images of effects form "ola invernal" flood event in Riohacha (September 2010 to November 2011).

On the other hand, people's behavior aggravates the problem: typically, when a zone is flooded, they take off the manhole covers trying to get rid of surface water sooner, but so overloading the sewer system and causing wastewater overflows in some districts downstream. Even worse, they do not properly manage rubbish, leaving it on the street where the rain washes it away. This rubbish then accumulates in the storm drainage system, eventually blocking it.

Another key structural problem is linked to the presence of the sea: it determines the lowest drainage level for the Riito, which, in turn, does the same for Laguna Salada through a box culvert connection, eventually affecting the whole system upstream due to backwater effects (Figure 4).

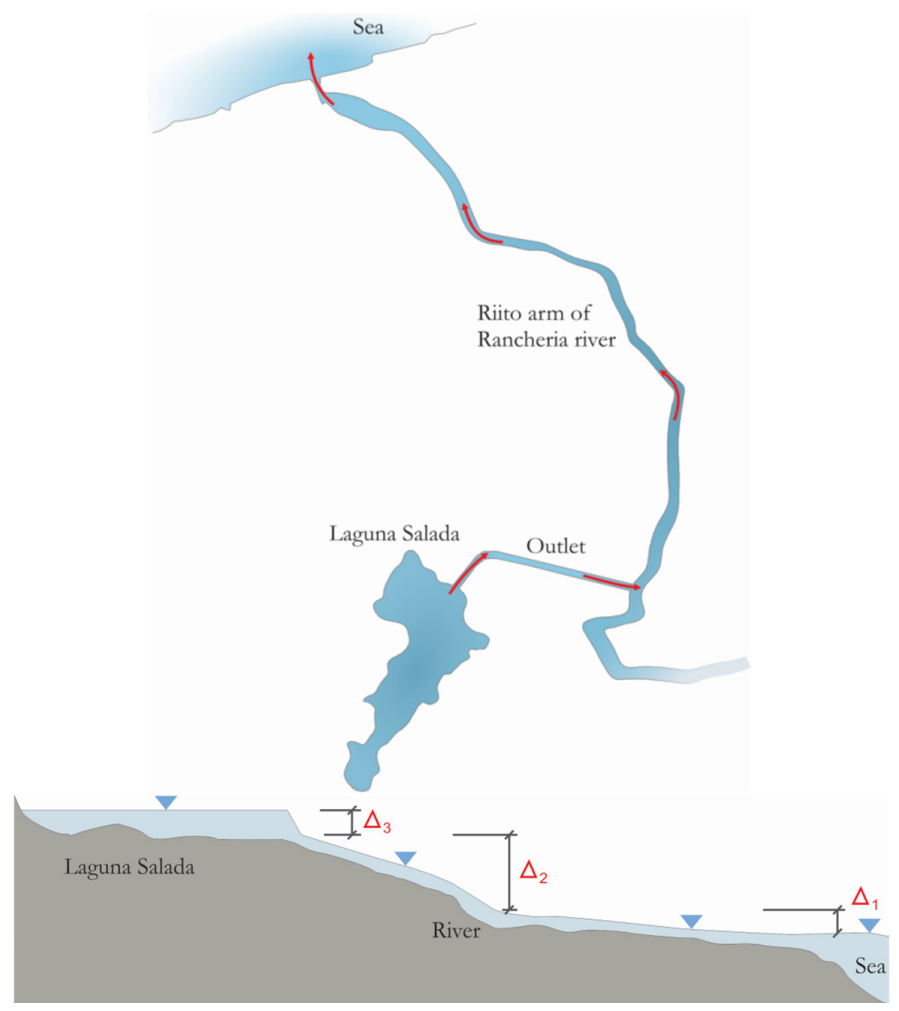

Figure 4. The sea level influences the hydraulic behavior of the whole urban system of Riohacha as a sequence of hydraulic head losses occur along water flowing downstream-diminishing the available head due to sea level rise and restricting discharge capacity. The distance between sea and Laguna Salada reaches a bit more than $2 \mathrm{~km}$, while $\left(\Delta_{1}+\Delta_{2}+\Delta_{3}\right)$ sums approximately $1.8 \mathrm{~m}$ before flooding the city. 
Looking at the future, foreseen urban development is a key challenge: apart from the center of the town, where only vertical growth is foreseen-and some areas have been declared natural reserves (particularly those lying to the East of the Riito)—the majority of the territory is likely to experience severe urban growth (local urban land use plan draft already discusses this issue, but the empirical evidence speaks more clearly and loudly). The consequence of increasing imperviousness, losing local water storage volumes and increasing exposed assets, can be dramatic for future flooding. An additional element weighs undoubtedly on this dynamics: the social pressure of a large number of people that are today homeless because of social violence (owing to "guerrillas" or "paramilitares") or economic weaknesses from which Colombia suffers. These unfortunate people typically build houses in the suburbs of growing cities (creating slums), selecting the last free zones, which obviously are the most environmentally fragile or degraded ones and the most prone to flooding. Some even take advantage of this perverse dynamics: they settle in these places and start exerting social and political pressure to get the local authorities to "do something" for them and so typically get some basic services (electricity, water supply, possibly sewer system, and then informal local transportation and shops). After that, they claim a formal right to live there, unwittingly increasing their vulnerability and undermining environmentally sound urban planning efforts.

Climate change ("CC") will definitely worsen the situation: a sea level rise is predicted [2-5] that, as depicted in Figure 4, will worsen the performance of the urban drainage system of Riohacha. Besides, the increase of rainfall intensity, for any given return period, or conversely the increasing frequency of flood occurrence for the same intensity, will aggravate the hazards. The Colombian government is well aware of this threat and already launched a national strategy for adaptation to climate change [6].

Lastly, it is important to stress that it is almost impossible to discuss flood control measures with a system approach without the aid of a mathematical model. However, as commonly seen in developing countries, there is little information available: topographic information is not completely reliable, the channels and storm drains are not completely known and definitely not fully surveyed and there are no data on flood levels or discharges associated with observed rainfall events. This situation poses another challenge by itself, particularly to calibrate the mathematical model.

\section{The Riohacha Project: Methodology and Contribution}

\subsection{The Project "Green Urban Adaptation" in Riohacha}

This paper describes the main elements of the integrated approach process undertaken through the project Adaptación urbana verde frente a inundaciones con el soporte de la modelación matemática y del software MODCEL ("Green urban adaptation towards flooding by means of mathematical modeling and the MODCEL software") to elaborate a plan for addressing Riohacha's flooding problem, while restoring environmental values and revitalizing urban assets. The adopted framework stems from Sustainable Urban Drainage Systems (SUDS) approach (see, for example, SUDS applications in [7-12]) and Urban River Restoration (URR) [13-19]. The planning exercise was based on mathematical modeling and GIS tools, adapted to overcome the lack of data, and developed along a participatory process to both conceive solution options and make them acceptable to the involved stakeholders, while looking for solutions that are socially attractive and economically efficient.

The adopted methodology can be synthesized as follows:

(1) Territorial-hydraulic characterization with specific surveys.

(2) Detailed inquiry of the local population to obtain data on actual flood depths to calibrate the proposed model-MODCEL [20,21]—(basically searching for flood marks in each house inquired); this step together with the previous one, allowed us to overcome the lack of data and to fill gaps about system topography and geometry.

(3) Prediction of future conditions related to climate change (both precipitation events and sea level rise) and population development. 
(4) Systematic review of existing studies/projects to create, together with people inputs, a portfolio of "solution options" and then, with these, a number of solution alternatives (denoted "ALTs"); notice that "solution options" refer to single measures, while a "solution alternative (ALT)" is indeed a full plan and has a specific meaning, being an organized package of solution options to be applied in particular locations and with specified characteristics. This is the term we adopt in the following.

(5) GIS algorithms to support database preparation and to estimate impacts (e.g., flooded areas and affected houses).

(6) Application of the MODCEL hydrodynamic simulation model for exploring system responses to alternative solutions.

(7) Integrated multicriteria evaluation of solution alternatives to assess their relative performance under different criteria considering the environmental, social, and economic dimensions. The evaluation was then complemented by a simplified but sensible Cost-Benefit analysis of the candidate alternative.

(8) Highly participatory process at both inter-institutional and community levels with a series of workshops and the conduction of an info point.

(9) Production of technical and educational informative material; and several dissemination, training and capacity-building events and publications.

The specific project outputs are a shared integrated plan, and an increased awareness and enhanced dialogue amongst the key stakeholders. A second phase is foreseen in which the plan would actually be implemented.

This paper describes the results obtained in the first phase, before the (pilot) projects' implementation. Its added value lies, we believe, in showing how different fundamental technical and participatory pieces of know-how can be combined in a harmonious, although complex, but still well applicable process that can be of help in many other similar cases in Colombia and all over the developing and emerging world cities. It stresses the advantage of adopting a fundamental change of paradigm in urban water management to avoid the evident unsustainable track experienced in so many cases so far, as briefly discussed in what follows.

A somehow similar experience, related to the dual problem of water availability, is described in [22]. There, a questionnaire was applied to local people to assess their subjective vulnerability and identify the underlying major causal factors; a simulation model was adopted to estimate water availability, conditioned to (downscaled) climate change scenarios; solution options were identified through a participatory process and, amongst them, a set of presumably most effective ones was selected. In our exercise, we add a step to this framework under a systems perspective, namely evaluating how the whole set of chosen solution options (the solution Alternative) would perform in terms of a number of criteria that are simple, but sufficiently informative to support a balanced and informed decision at the political level.

This paper does not claim to bring a specific scientific knowledge innovation with respect to a particular finding or technique; rather, its aim is providing a more practical contribution by "telling the whole story about how a thorough plan for urban flood adaptation based on an articulated and integrated process can be elaborated". We believe this experience is rich exactly because of the diversity put together. Additionally, lessons learned are summarized, which convey an additional, practical added value.

\subsection{Evolving Paradigms to Address Urban Drainage and Flood Management}

The approach originally coined for basic sanitation purposes dates back to the industrial city period, when it was important to collect, conduct and dispose of storm and wastewaters quickly. The underlying philosophy was trying to "get rid of water as soon as possible through drainage canals" (either superficial or subterranean). It is now recognized that-because of the fast urban growth in the 
last two centuries-this approach was responsible for transferring floods downstream (and shifting problems from one place to another), revealing its intrinsic unsustainable character.

This approach has been evolving over time; for instance, Andoh and Iwugo [23] highlight that measures to counteract the causes of flooding-enhancing local storage and infiltration capabilities-were already introduced from the end of the 1970s, in response to the initial discussion about sustainable solutions for urban drainage. In this context, several specific approaches were developed: Best Management Practices (BMPs) [24], Low Impact Development (LID) [25,26], Sustainable Urban Drainage System (SUDS) [25,27] and Water Sensitive Urban Design (WSUD) [28-30], among others, all trying to recover (as much as possible) the natural functions of the hydrological cycle, while adding value to the city itself. Fletcher et al. [31] broadly discuss the evolution (and terminology) of urban drainage debate around the world.

A particularly promising approach merges SUDS with Urban River Restoration (URR). Indeed, on the one side, SUDS approach aims at reducing the peak flow into the drainage system (while assuming it cannot cope with the highest floods). To this aim, SUDS enhances the system capability to retain water locally (with rain harvesting in each building block, or within squares or multifunctional parks suitably modified), or to infiltrate (e.g., in filtrating parking areas), and takes advantage of urban-landscape elements to convey water (along streets) to support the role of the drainage system in critical events.

A key aspect of this combined URR-SUDS approach in a context like that of Riohacha refers to recognizing the buffering role of wetlands as water retention measures, as depicted in Figure 5: when an incoming flood finds a still empty wetland (which is likely to occur if a suitable small water escape is created at the minimum level desired, controlled by an outlet), a large part of it gets temporarily trapped and the outflow hydrograph is greatly smoothed. This means that an increase in the storage capacity of a wetland and a proper modification of its spilling threshold and/or of the outlet elevation and diameter can influence the rest of the system downstream.

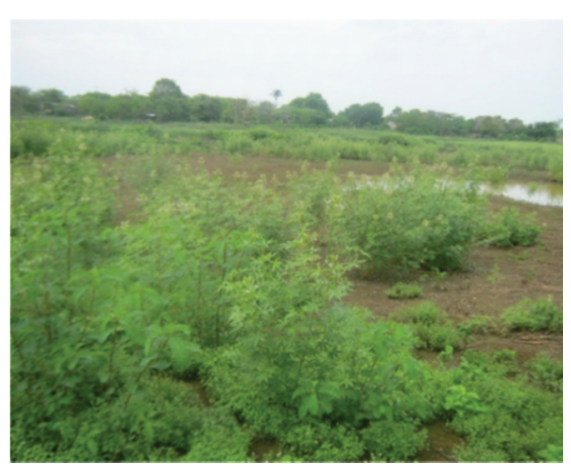

(a)

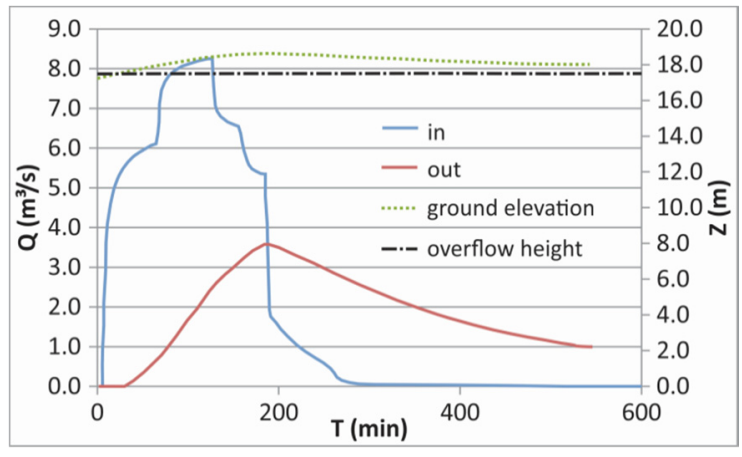

(b)

Figure 5. Mano de Dios wetland: (a) the wetland today (semi-dry conditions); and (b) the outgoing hydrograph (lower curve) is much smoother than the incoming one.

Different municipal administrations of Riohacha have addressed the flood problem over time and have also been trying to improve the environmental assets of the town, centered on the "humedales" (wetlands). However, in the end, little effective action has been undertaken on the ground. Undoubtedly, their approach has so far been that of traditional hydraulics discussed above, which, in Riohacha, proved its serious weaknesses even more than usual due in part to the topography of the area and presence of the sea (Figure 4) and in part to the behavior of the people that inevitably leads to inhibit their functioning. The attempts carried out in Riohacha so far were also myopic, i.e., addressing each time a specific local problem while disregarding its connections with the rest of the system, thus compromising the results. Indeed, only a system view can provide the mass balance tracking behavior, showing that the volume subtracted somewhere and displaced in time and space 
can modify the performance of the whole system: this is a fact that links all possible interventions and that was not considered previously in the locally oriented solutions. This system approach has been applied in our project where several packages of possible solution options were combined and evaluated via simulation, by means of a mathematical modeling, which allows a transparent and consistent quantification of effects.

\section{The Supporting Tools: GIS and MODCEL}

Two key tools have proved fundamental in this project: the Geographic Information System (GIS) and the urban flood simulation model called MODCEL.

\subsection{Role of GIS in Capturing Information from the Inquiry}

The GIS allowed bringing together all the pieces of information linked to the territory and even a large part of the information verbally conveyed by people during the workshops, the inquiries and the interviews conducted in the participatory process developed (as is shown later). In particular, a key functionality was the ability to report geographically the site where a house was flooded together with the local flood depth. These data were then inter-extrapolated in a flooded surface by using topographic information (elevations). In the field surveys, the team had no way to measure the elevation of the water in the flooded areas; only local height differences could be measured, as shown in Figure 6.

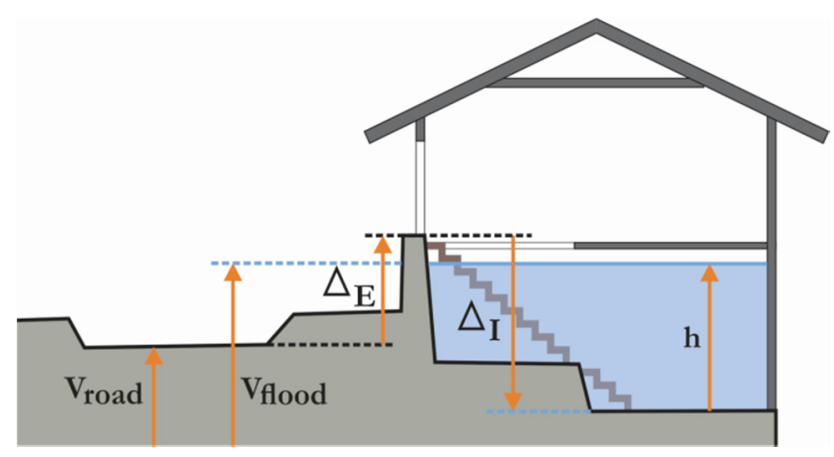

Figure 6. Scheme adopted to reconstruct the elevation of the water table in flooded areas-the flooded water elevation can be calculated as $\mathrm{y}_{\text {flood }}=\mathrm{y}_{\text {road }}+\Delta_{\mathrm{E}}-\Delta_{\mathrm{I}}+\mathrm{h}$.

Note that $\Delta_{\mathrm{E}}$ in Figure 6 is the relative height difference between the external road in front of the house and the entrance threshold (some houses have a kind of protecting gate/barrier); $\Delta_{\mathrm{I}}$ is the height difference between that threshold and the lowest floor-both taken with their algebraic sign according to figure convention-and $h$ is the flooded water depth of the lowest sector of the house (residents indicated the level reached on a wall): these three terms were measured on the field, while $\mathrm{y}_{\text {road }}$ is the elevation of the road in front of the house (automatically given by the GIS DTM). The extrapolated historical flood maps were produced as reference information for MODCEL calibration purposes. It must be noted that such maps are affected by high uncertainties because: (i) some of the persons interviewed were not present during the historical flood events (so some did not report being affected although living in the middle of a clearly flooded zone); (ii) some answers were imprecise or even wrong because of memory weakness or even deliberate exaggeration (in view of some possible governmental help); (iii) topographic information available is affected by significant uncertainty (e.g., some sectors of the streets have been paved posteriorly to the original topographic survey); (iv) the flood map loses meaning far from measured points, especially near the boundaries of the watershed-because information is sparse and it is difficult to identify outliers; (v) water levels may refer either to flowing water or inundation; and (vi) extrapolation brings greater uncertainty than interpolation. 
Another key element present in people's minds was "how water moved" during significant floods. By organizing on paper the inputs verbally given at each house where an inquiry was carried out, this information was later translated to a GIS shapefile, to produce the map illustrated in Figure 7, which was indispensable to refine and sometimes correct the available topography (contour curves) and then used to support the (not trivial and iterative) process of cells definition as well as the identification of hidden obstacles. The flow information is also very useful to choose the most suited type of interconnection link amongst cells.

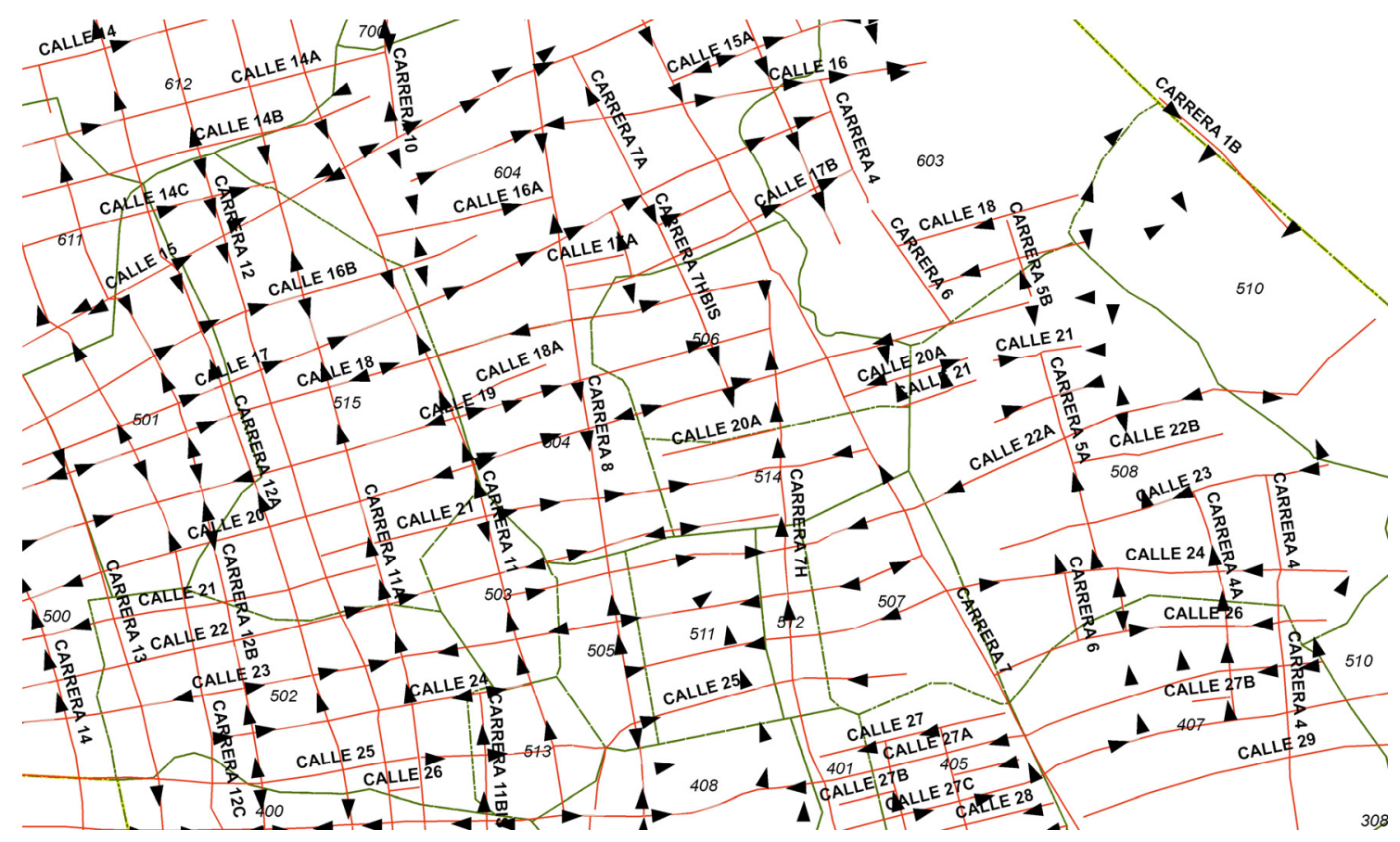

Figure 7. Flood flow directions (zoom) indicated by people and reported, once geo-referenced, in a GIS project.

\subsection{MODCEL}

MODCEL [20,21] is a hydrodynamic urban flood simulation model which partitions the watershed into a number of cells, which work as ponds (with storage capacity) and are interconnected by hydraulic links specified amongst a vast array of possibilities. The cells usually work together to build more intricate structures and to represent natural terrain topography or urban patterns. Sometimes, the cells mainly act as conveyors, as in rivers, pipes, storm drains or runoff over floodplains. In this case, the main hydraulic link is described by the dynamic Saint Venant equation. Other times, the storage effect is preponderant.

A synthetic view of MODCEL main features is shown in Figure 8. Its main outputs, given a hyetograph (i.e., the pattern of rainfall intensity along time for any given event) and the boundary conditions (levels or flows or stage-discharge relationships at the borders of the modeled area), are the water depth reached in each cell "center" (i.e., the reference for calculations), as well as the exchange flows along all connections. Some applications of MODCEL may be found in literature (e.g., $[7,12,32,33])$. 


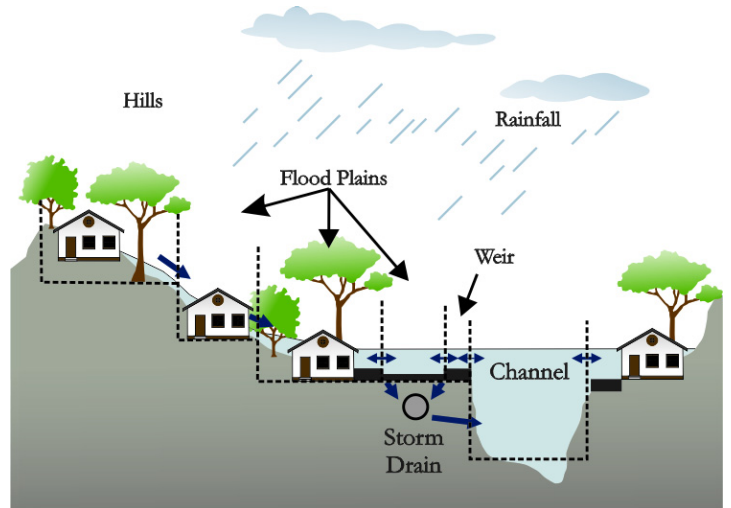

(a)

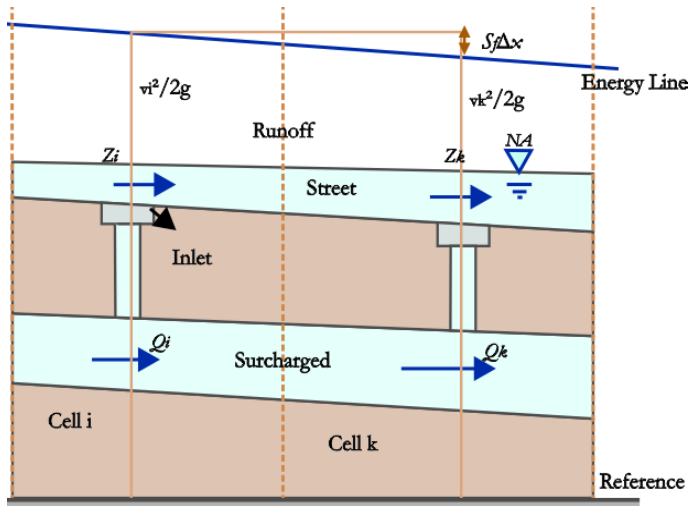

(b)

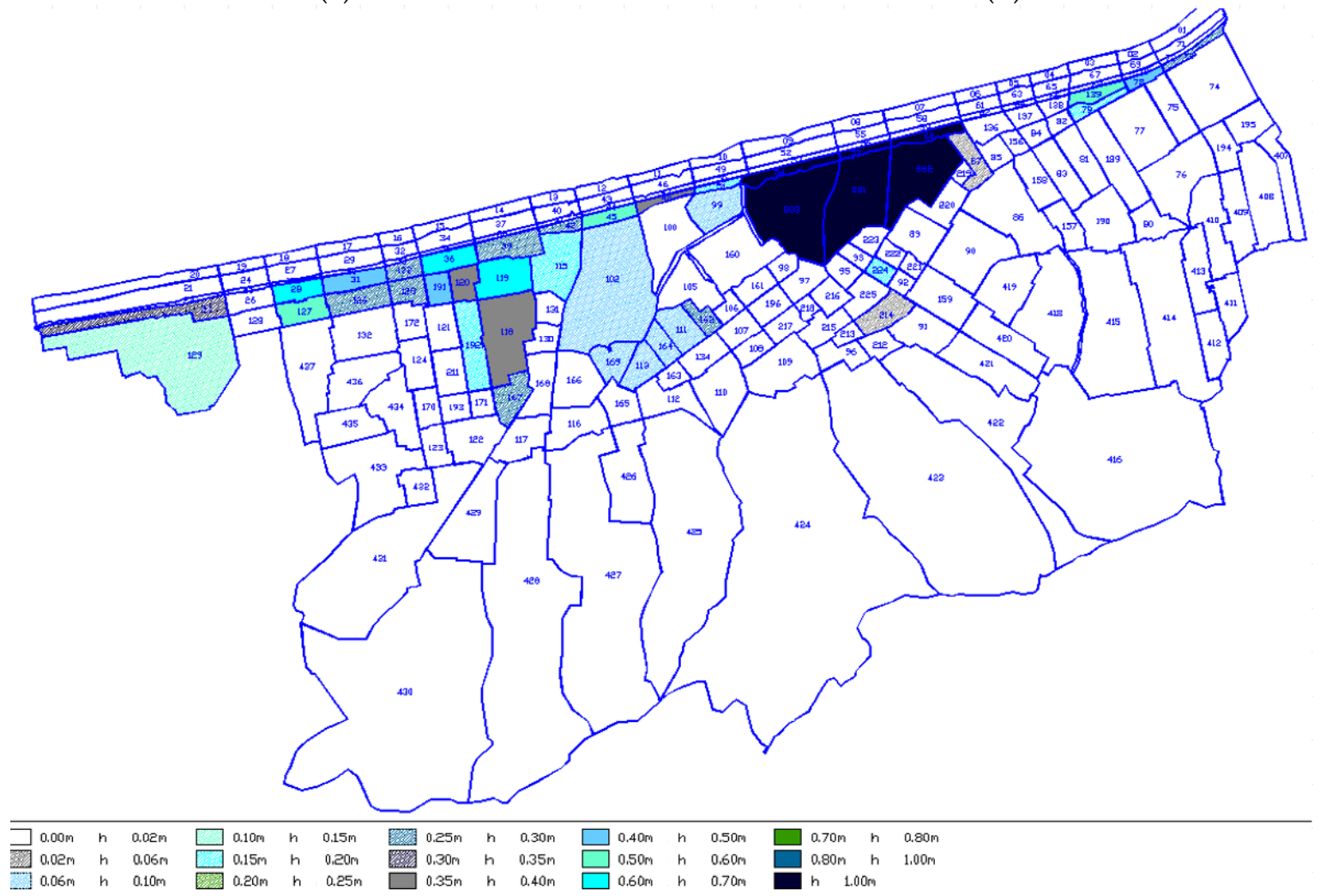

(c)

Figure 8. Main concepts of MODCEL model: (a) types of cells (discrete portion of the territory that can store and release water in connection with others around them); (b) the quasi-3D capability of MODCEL; and (c) typical model output: cells flooded with their flood depth, corresponding to a given setup.

In what follows, a specific discussion about the meaning and suitability of adopting such a kind of model is presented, as this tool was a key element to support the planning process described in this study.

MODCEL concept was based on the original work from Zanobetti and Lorgerè first published in 1968 [34]. The cell concept was originally developed to overcome computation limitations for simulating large flood plains. However, some of its characteristics, due to a modular construction, can be very useful, even nowadays, for urban systems simulation, where natural topography patterns, urban landscape, and hydraulic structures merge in a complex setting.

Abily et al. [35] bring a very pertinent discussion about possibilities, performances and limits of the use of standard modeling tools for high resolution runoff simulations over an industrial site as 
an example of an environment of dense and complex aboveground structures that affect drainage paths. An urban environment can be equally complex; thus such discussion hence retains its pertinence. These authors stress that models based on 2-D shallow water equations are being used to model urban areas and high-resolution topography data are becoming available to support these models. However, they also stress that modeling of complex sites deserves special consideration and 2-D modeling could be challenging: rapid changes in flow regime, small water depths and high gradient properties, some of the aboveground components may introduce vertical effects in runoff hydrodynamics, etc. We can add to this picture that wetting and drying of model elements can also be a challenge and, several times, it is not possible to see a real continuous 2-D surface moving over the urban watershed. Walls or earthworks may produce independent surface flows connected by weirs or orifices, for example. In these situations, in particular, MODCEL proves its strength as different flow patterns may coexist.

In their study, Abily et al. [35] tested two 2-D models (Mike 21 and Mike FM [36] and one 3-D Finite Volume Method (3D-FVM). The results pointed to Mike 21 having difficulties with detailed small-scale infrastructure representation, while Mike FM was more adapted to fine representation, but able to handle high gradients as well as Mike 21 did. The 3D FVM showed a better behavior, but with significant work for mesh construction and computational costs. A final word of the authors also mentiones that field measurements would have been desirable to validate models.

Although 2-D modeling is becoming more common everyday, and efforts are being made to benchmark models [37,38], lack of observed data seems to be a common problem when comparing model simulations to real floods, in order to evaluate model accuracy for spatially distributed real world events (e.g., [39,40]).

Neal et al. [41] argued "How much physical complexity is needed to model flood inundation?" In this study, these authors state that, besides topography, "a number of less obvious factors also cause differences in simulations as great or greater than physical complexity". For the cases of subcritical gradually varied flows, simulations of velocity, depth and inundation extent from the different tested models were broadly consistent amongst the different tested models, with differences only as large as the ones caused by other modeling choices (e.g., topography sampling, recording of results, etc.).

More generally, another important issue is that even with the most accurate DTM (built with accurate LIDAR technology), one will never be able to identify the actual anomalies of the drainage system (such as frequent obstructions in the manholes, blocking of box-culvert section or flap, presence of rubbish in the canals, or the behavior of people during an event). Only the information gathered on the field through interviews and a systematic inquiry to the local people-leading to a product like the map of flow directions (shown in Figure 7)—can supplement this "information hole". The strict 2D (or even 3D) modeling, especially if one relies exclusively in the model complexity as a guarantee of quality results, may be too vulnerable to information gaps and unavoidable imprecisions.

MODCEL, on its turn, can be considered quasi-3-D, as it is able to describe the inundation process on the surface of both natural or artificial water courses and elements of the urban fabric (streets, squares, roofs, etc.), the flow in the subterranean storm drains or sewerage network, and the mutual "upper-lower layers" connections amongst such elements, including the (common) overflow of the grey-black water over the urban surface. It does this, however, by properly composing only 1-D equations, thus preserving simplicity and sparing computational time.

It is important to note that, MODCEL cannot function by a blind, automatic application of geomatics tools and objective description of boundary conditions and meteorology forcing factors; it rather obliges the modeler to deeply investigate and understand how the real system is functioning and where/how can each component be represented. At a first glance, this could be seen as a weakness, but, in fact is turned into a strength: through this process, indeed, inevitably the bottle-necks of the drainage system come to light and an actual, very useful understanding of the system behavior is gained which can very well lead to identify the relevant solutions.

Topographic and hydraulic representations are two core elements in MODCEL. It is important to point out, however, that MODCEL does not need a Digital Terrain Model (DTM) in the strict 
sense. In fact, it only requires synthetic geometrical information characterizing each cell and each connection, information that can be derived from a DTM or crude topographic data. It involves indeed a preliminary process of physical interpretation that is crucial in the modeling process, in order to identify and translate in a concise way the information provided to the model.

At last, an important discriminant argument to accept or not a particular model is as follows: if a model behaves sufficiently well in calibration and validation (and requires very few parameters to be calibrated), there is scientifically no reason to object that it "serves the purpose" and no reasons to refuse it. It should be recognized that in general there is no best model in absolute terms, but models that are suited for a specific purpose and within a given context (e.g., data availability, economic resources to be dedicated, etc.).

\subsubsection{Model Calibration and Validation}

The challenge is to calibrate a conceptual model, like MODCEL, by using data taken from the real system. Each cell is characterized by an elevation-storage volume curve (actually based on topography for some types of cells, or defined in a schematic way, for flatter urban areas, based on the width and depth of streets with respect to walkways, density of houses, etc.). Its dynamic water-balance determines the storage in each cell and accordingly it is possible to determine the maximum flood elevation reached during the simulated event. By assuming the cell-center water level as representative of inundation within the cell, its intersection with the topography (DTM) identifies the flooded areas and associated water depths (and elevations). This information can then be compared with the values measured in the field (as explained before) to compute a deviation indicator, which produces a performance index to be optimized via calibration. Attention has to be paid, however, to those field measurement points falling just on connection links: for them, a comparison between simulation and measurements only makes sense in terms of water depth " $\mathrm{h}$ " (not elevation " $\mathrm{y}$ "), as these points do not belong to the pseudo-horizontal impoundment zones and their hydraulic characteristics depend basically on the flow rate exchanged, rather than on the volume stored. Furthermore, such depths are usually very low (some only centimeters or less) and topographic uncertainty would greatly affect the result.

A closed urban watershed was defined for our case study in Riohacha (after several attempts and progressive upgrades), which is shown in Figure 9 together with the prevailing communication pathways with the external world. It is important to notice that defining an urban watershed is not a so easy task and it is valid only within certain range of flooding levels, because when topography is typically quite flat (as in this case), the occurrence of a sufficiently great water depth may establish a (non-predefined) connection with the external world, hence modifying the boundary and definition of the original watershed. In particular, multiple outlets are possible, although in our case the main one follows the thalweg marked by the urban wetlands. As boundary conditions we assumed the sea level reached during the event for the box-culverts to the north and the level of the Riito surface upstream, along the northeastern boundary of the urban catchment with the Rancheria delta (circumvalar road, see Figure 9); such (plausible) levels were determined through interviews with local fishermen and inhabitants.

Once the iterative process of definition of the physical system (cells, boundaries, interconnections and associated features including spilling thresholds, channel size, etc.) is completed, calibration reduces to adjust the runoff coefficient according to different land uses and the Manning's roughness coefficient (which applies differently to canals, pipes, streets, and superficial flows). Some other classic hydraulic coefficients, used to represent for example flow over weirs or through orifices (features of the connection links), also have to be calibrated, but play a secondary role.

The historical event of September 2011, the most intense and harmful of the "ola invernal" ("winter wave"), for which we estimated a return period $\mathrm{T}_{\text {Sept.2011 }}$ of about 84 years (in the current climate context), was assumed for calibration purposes. This event showed a storm duration of approximately three hours with an accumulated rainfall of almost $200 \mathrm{~mm}$ (Figure 10). 


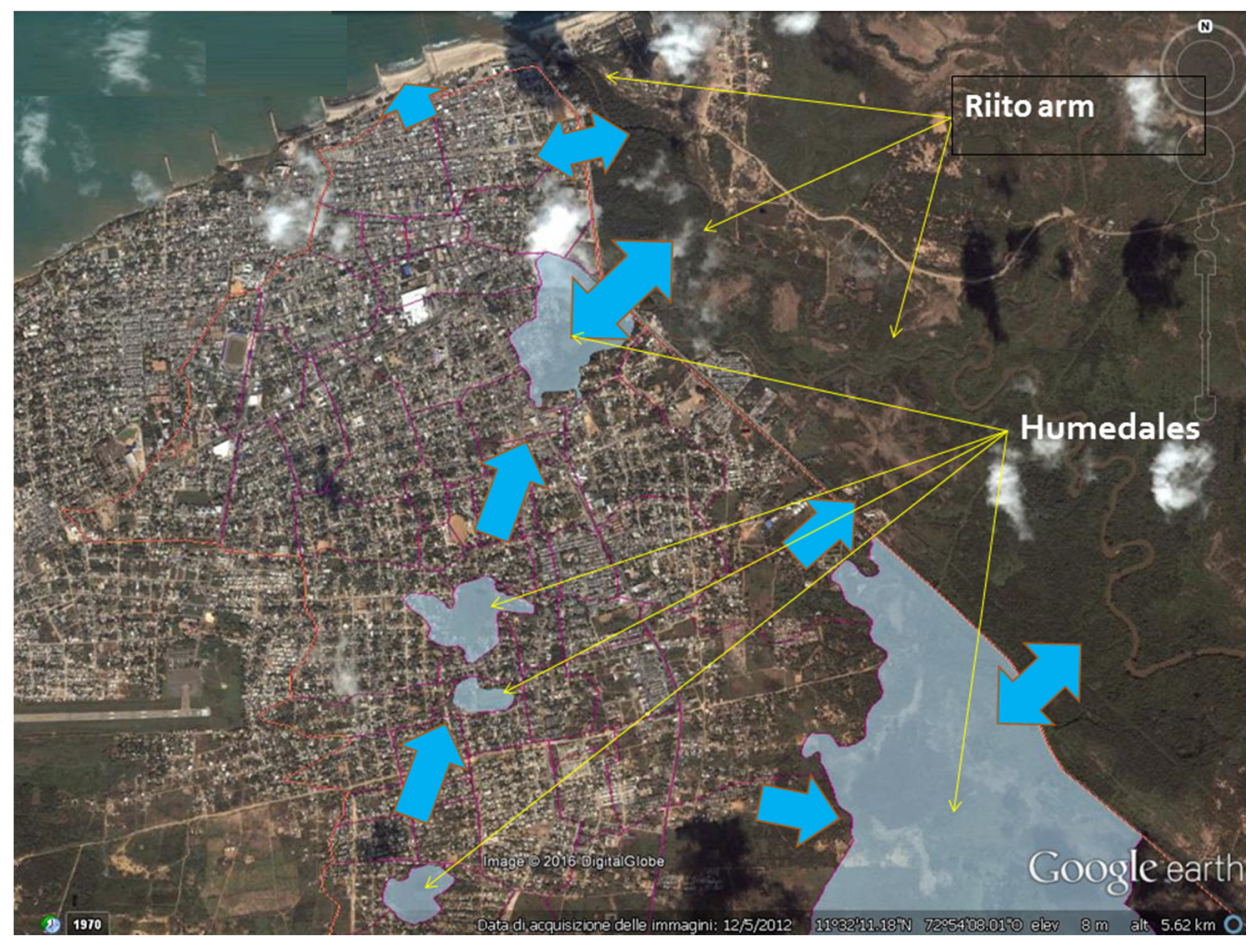

Figure 9. The urban watershed considered (yellow boundary) and the MODCEL cells that partition it, together with the prevailing drainage pathways (blue big arrows) through the wetlands ("humedales") and the communication gates with the external world (the dots represent box culverts under the main road earthworks). At the right, after the main border road (the circumvalar), Ranchería River is visible with its delta region; the Riito arm is the one closest to the town, flowing in the upward-left direction.

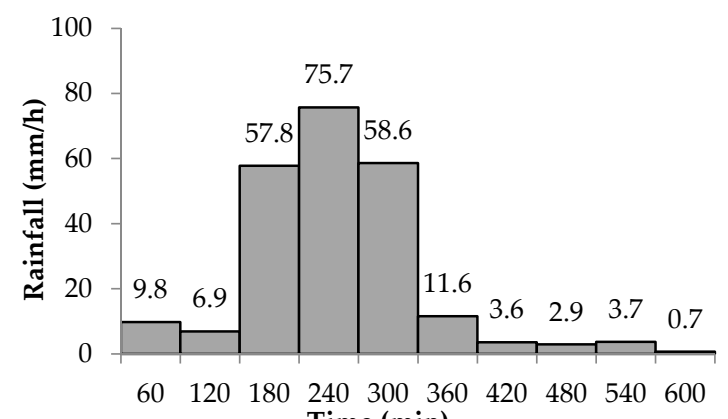

Figure 10. The pluviograph reconstructed from original measurements at Almirante Padilla Airport gauging station in Riohacha (source: IDEAM, Instituto de Hidrología, Meteorología y Estudios Ambientales de Colombia) of the September 2011 event. This has been utilized for model calibration and then adopted in the simulations.)

A GIS supervised classification procedure was applied by assigning a number of points on the map to different land use zones in order to obtain from the algorithm a full assignment of land use type to the whole territory; then, a fixed correspondence of the runoff coefficient was adopted and applied (e.g., 0.65 for built areas; 0.95 for streets; 0.30 for vegetated areas; 1 for water bodies). The calibration process was actually carried out by a manual iterative search of adequate values for the set of adjustment parameters (e.g., Manning coefficient of 0.085 for superficial flows occurring on streets acting as canals; 0.15 for broad crested weirs; and 0.60 for orifices), which provided a suitable fitting according to a detailed inspection of the behavior of each cell (output currently provided by MODCEL 
software in an Excel spreadsheet). Some objective performance measures were also considered, obtaining values of $0.05 \mathrm{~m}$ for the medium difference between calculated values and measured values and of $0.04 \mathrm{~m}$ for the standard deviation Figure 11 shows calibration results, separating cells where comparison with field measurements had to be carried out on the basis of water depth $\mathrm{h}$ (Figure 11a); from cells where comparison had to be performed based on elevation $\mathrm{z}$ (Figure 11b). The calibration results obtained were considered adequate by assuming a tolerance of $0.15 \mathrm{~m}$ for each measure and fulfilling the condition that, when more than one field measure were available for the same cell, MODCEL output should have a value falling amongst the measures. Validation results (carried out with another significant rainfall event, occurred in November 2011 and not fully reported here for reasons of space, but available in the project report) were also acceptably good. For this validation event, we obtained $0.14 \mathrm{~m}$ for the medium difference between calculated values and measured values, with a standard deviation of $0.11 \mathrm{~m}$.

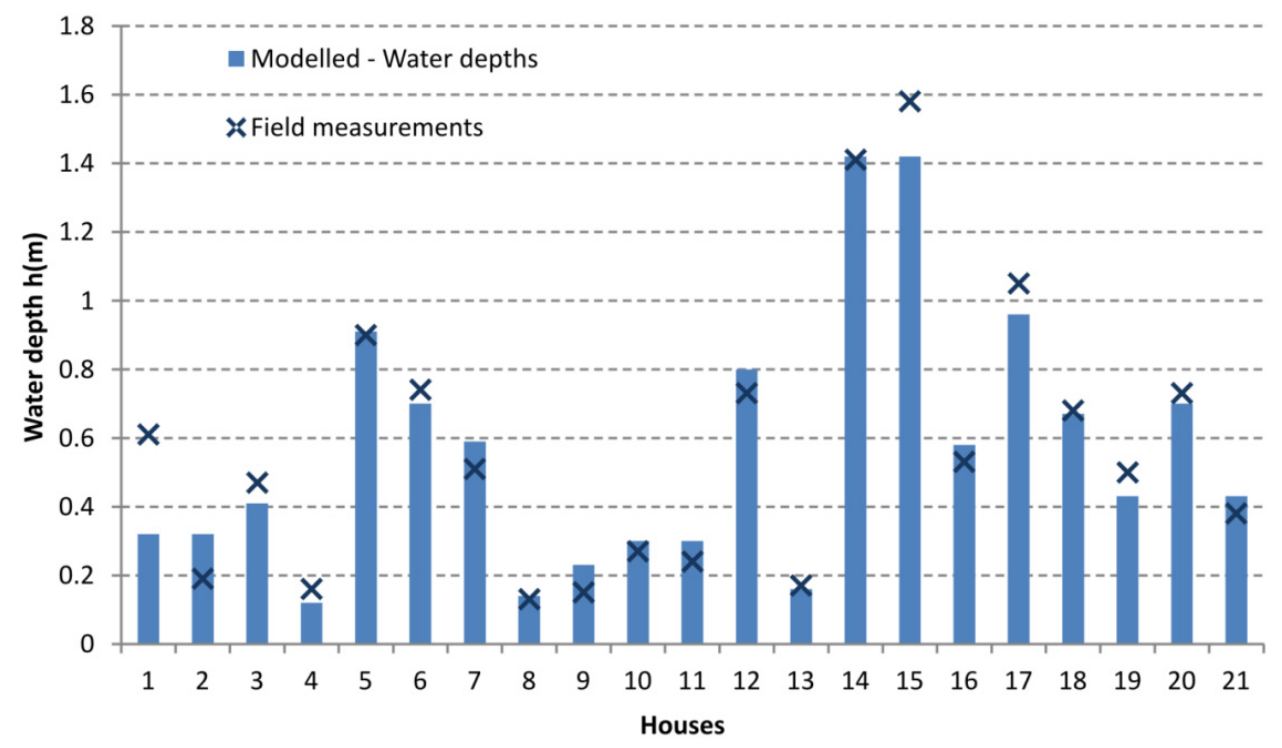

(a)

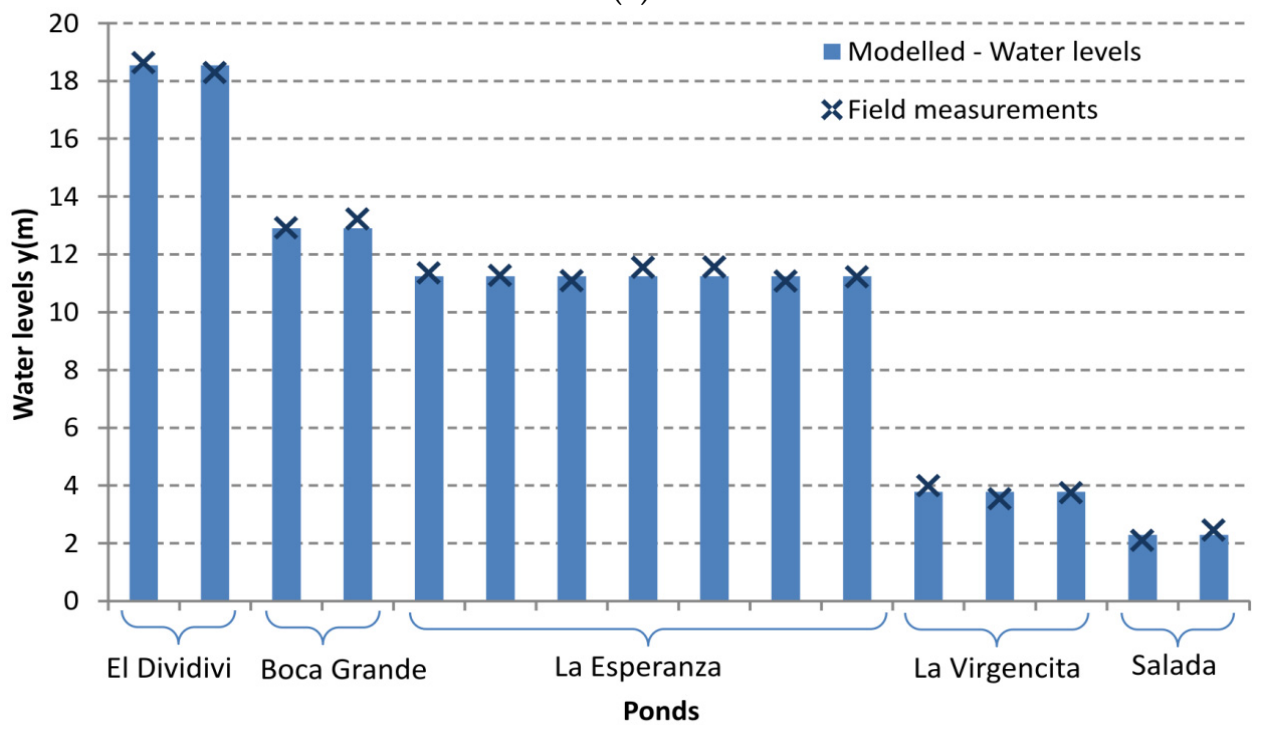

(b)

Figure 11. Calibration performance: (a) cells calibrated using water depth; and (b) cells calibrated using elevation z. Crosses correspond to field measurements used in the process. Some field measurements were discarded after an objective and rigorous process that identified doubtful or evidently wrong cases (fully documented in the associated report of the complete project [42]). 


\section{Multi-Objective Participatory Framework}

\subsection{Participatory Process}

This project dedicated significant efforts to an effective participatory process, although with limited resources. It acted both at the community and institutional levels. It promoted an effective round-table discussion involving, possibly for the first time, through a number of multi or bilateral meetings all the relevant institutions and subjects concerned with urban planning and management: municipal government (environmental and planning sectors), the technical office for the POT development ("Plan de Ordenamiento Territorial", i.e., the urban land use plan), CORPOGUAJIRA (the regional environmental authority), Gobernación (the regional administrative authority), IGAC (the regional section of the national institution for land cadastre), the Civil Defence, Fire Department, Red Cross, COMFAGUAJIRA (a private service to ensure wellness and protection of the family, responsible also for housing) and the UNGRD at the national level. All the meetings were documented with attendance list, photos and minutes.

At the community level, the key actions involved:

- The "inquiry", a structured survey carried out in approximately 450 households with a detailed, pre-defined form in order to: (i) obtain the most reliable data on historical flood levels to calibrate the simulation model (as discussed previously); (ii) improve knowledge about the local water paths during flooding (as shown in Figure 7); (iii) gather information for empirical estimation of flood damages (or at least a comparison with technical estimates); and (iv) assess people's attitude towards possible solutions. This four-month phase proved to be indispensable and the information obtained was stored in an Access ${ }^{\circledR}$ Data Base (DB) designed ad hoc through which it is possible to create output report tables for the different purposes. This DB has the potential to become an operational tool in the future to register in a systematic fashion the information concerning future events.

- Public events, beginning with the project kick-off in March 2014, where people expressed deep disappointment due to longstanding promises followed by little concrete action.

- Several local workshops to cover all the urban districts, to present the project to the people and thus obtain information about local problems, identify local solution proposals (to be considered and tested), present the partial conclusions from the study and openly discuss pros and cons of the options for inclusion in the solution plan. A key result was the engagement of people, overcoming the first negative impressions (highlighted in the previous item), and also a first step of education about key behavior of possible solution options.

- A permanent information point ("Casa abierta"-Open house) where information concerning the development of the project was progressively updated and put in front of people with the presence of project staff twice a week, to provide explanations and gather comments and suggestions.

- Educational tools to be brought to schools and to the families through children, namely a booklet ("Cartilla") on typical wrong and right behaviors concerning floods; and a social game (a bit like Monopoly) called "Construye tu casa" (Build your house) through which again typical behaviors can be tested versus the possible hazards while going through the bureaucracy, corruption and technicalities in order to build a new house in a growing town (both tools are available at the project web page: http://modcelrhcdatos.wix.com/modcel-riohacha).

\subsection{Key Objectives and the Need for an Integrated Evaluation Framework}

The project made participants aware that, according to the system approach, any solution measure in a certain place in the watershed, while possibly improving the situation there, can provoke adverse effects elsewhere, because all components of a system are spatially and temporally connected. It also put in clear terms that although protection against flooding is the primary objective addressed, it cannot be the only one and a multi-objective approach is indeed unavoidable and can, moreover, promote the 
identification of better solution strategies. In particular, a second clearly relevant objective identified by the public authorities is the enhancement of the environmental conditions, taking advantage of the potential offered by the wetlands and their interrelation as parts of a natural hydraulic system, and by increasing the urban green area. Note that the environmental enhancement also includes the built environment, with social connotations. Besides this, another objective comes into play with strong weight, which is the implementation cost and the Operation Maintenance and Replacement (OMR) cost, i.e., the money that the responsible actor must gather and partially spend each year to keep in "good shape" and efficiently functioning the infrastructures present in the system. Finally, undoubtedly several people will be affected directly by the solution measures, implying the need for removal or adaptation of houses; the social disturbance is hence a further and very meaningful objective (to be minimized in this case).

When a problem presents multiple objectives, inevitably multiple solution alternatives ("ALTs" in what follows) must be considered, because one can perform better for a given objective, while another is the best for another one, but possibly no one performs simultaneously as best for all the objectives (in this rare case, the objectives are not conflicting, but in practice as soon as costs are involved, this is almost never the case).

In addition, the participatory nature of the project requires ALTs: any interest group can be promoter or supporter of a given ALT that he sees as preferable, often before having analyzed the associated effects with sufficient insight.

The ALTs identified are presented in Section 5.1 of this paper.

\subsection{Solution Options: Systematisation of Proposed Options}

The ALTs were not built from scratch. An effort was made first to collect and organize in a structured fashion (see Figure 12) the solution options already formulated either by institutions (studies and projects), or the community itself (as identified during the participatory process), or by the CREACUA team conducting the project.

The project team processed this valuable information (that sometimes led to contradicting actions) and determined that any solution option could belong to a given number of types; namely:

(1) Floodable urban parks and recreation areas/fields

(2) Storage measures: rain collecting roofs with cisterns

(3) Infiltration measures: permeable parking areas

(4) Connectivity improvement of the wetlands (recovering natural thalweg continuity)

(5) Morphological modification of wetlands (increasing volume and optimizing outlets)

(6) Artificial surface and subterranean drainage canals and pipes

(7) Artificial subterranean storage tanks

(8) Pumping stations

(9) Defense works (like dikes to protect particular areas or assets)

(10) Change of land use (constraints for future urbanization)

(11) Adaptation in situ or removal of houses (to avoid flooding by eliminating exposure) and their reconstruction elsewhere.

During the development of the project, and in interaction with the institutional and community actors, several concrete possibilities were selected, which gave rise to the ALTs actually conceived and considered, as shown in a later section.

\subsection{Linking Solution Options to Effects}

It was necessary to clarify the relationships existing amongst each solution option and the relevant effects. Figure 13 shows an example of the relevant cause-effect relationships for the Risk objective in particular. Several other schemes like this have been prepared and then implemented through GIS and Excel tools to set up a whole cause-effect operational framework. 


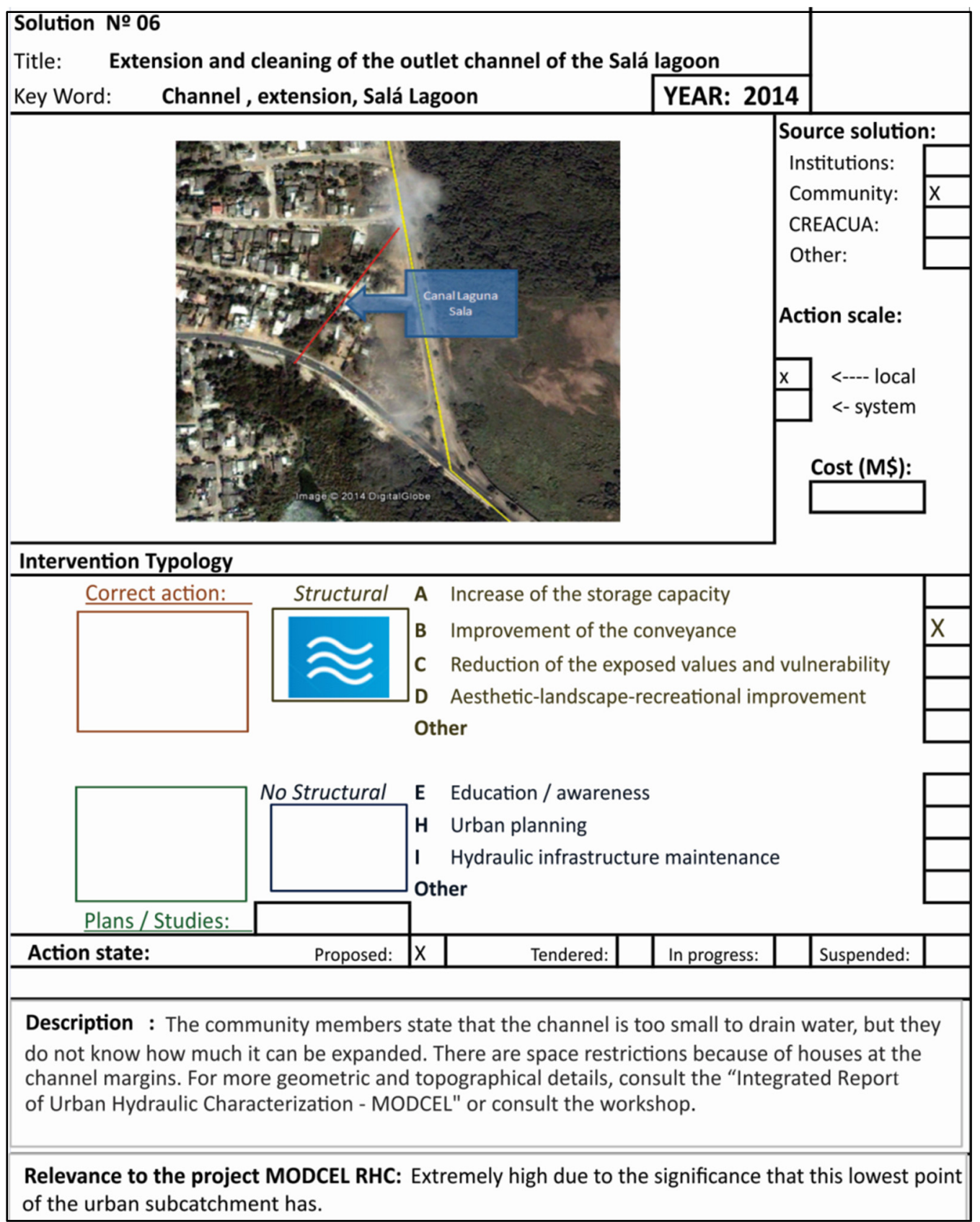

Figure 12. The FORM (with an example) adopted to systematize the description of the solution options already emerged, either from institutions or the community or the project team (CREACUA).

The scheme of Figure 13 implies an intersection of the shapefile of flooded zones and that of potentially exposed future houses. The former shapefile is obtained via simulation, with the given precipitation hyetograph and boundary conditions corresponding to the selected return period TR(i), and given the physical configuration of the whole system once the solution options indicated were applied. The set of vulnerable houses expected in the future (exposed to flooding) is determined as the set of future houses (existing plus foreseen) except those falling in unbuildable areas (a constraint given by the land-use change measure) and except those that are to be adapted or removed, according to the corresponding land-use change measures. 


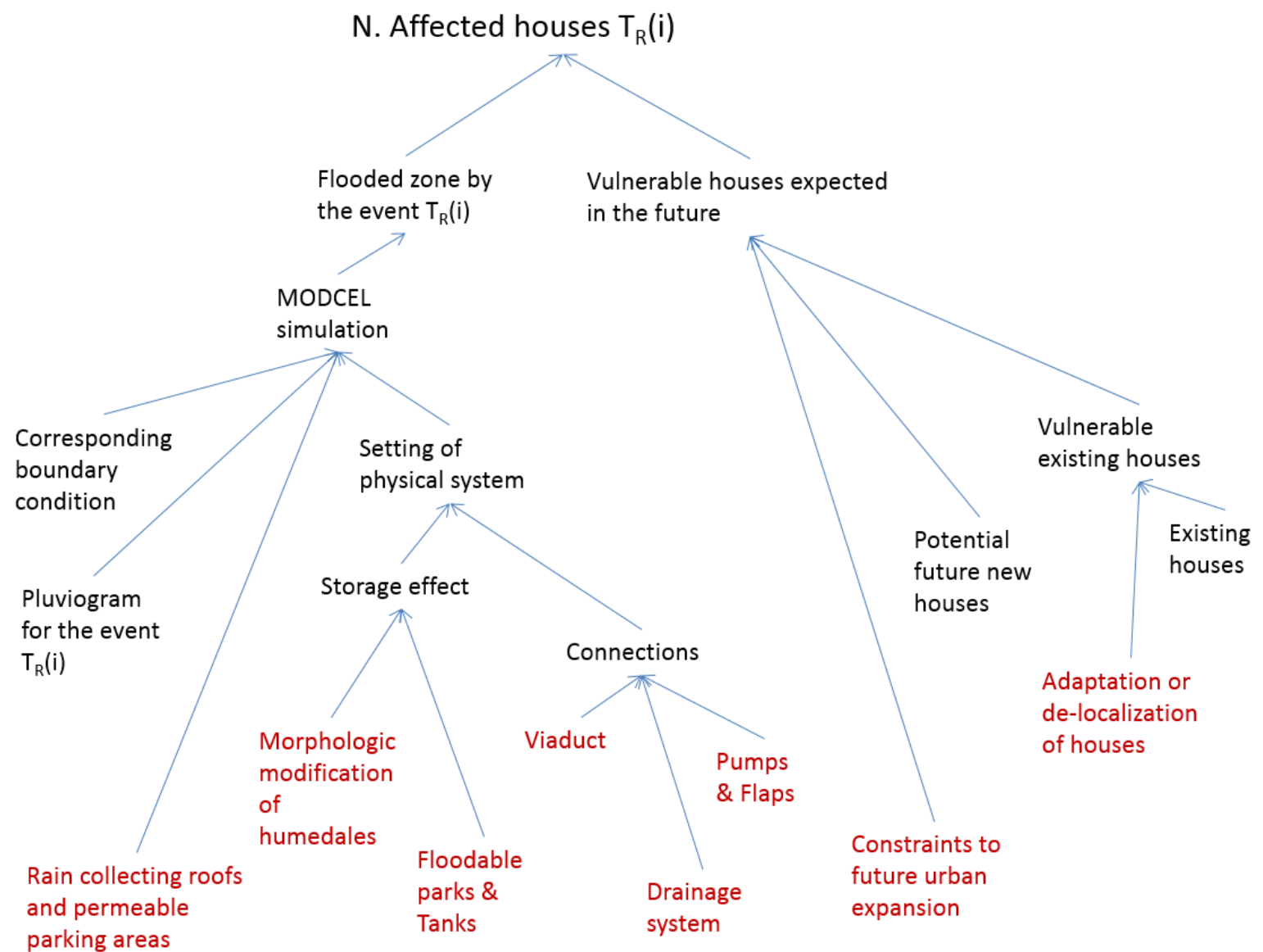

Figure 13. Cause-effect scheme linking solution options belonging to any given "alternative" to the indicator "number of houses affected by flooding for a given return period TR(i)".

\section{The Solution Alternatives (ALTs) and Their Evaluation}

\subsection{Conception of Solution Alternatives}

An "alternative" (ALT) is compound of elements taken from the solution options and specified in terms of size, location and technical features. The set of alternatives considered basically includes: doing nothing; maintaining present course of actions (the classic policy of local action); changing to a sustainable urban drainage approach; adopting an environmental approach; a combination of measures that maximizes the effects of flood control; and a realistic combination that considers the costs involved.

The conceived alternatives (ALTs) can be seen in Table 1.

\subsection{Synthetic Presentation of the ALT_R: the Proposed Plan for Flood Risk Control}

A short presentation of the contents of ALT_R is given in Figures 14-17 (further details are not visible at the figures' scale): 
Table 1. Set of considered alternatives.

\begin{tabular}{|c|c|c|c|c|}
\hline & Alternative & Vision & Objective & Strategy \\
\hline (1) & ALT_0 & Go on without interventions & Perturb the status quo as little as possible & Do nothing. \\
\hline (2) & ALT_Base & Go on with the approach implemented up to now & Try to make the city safe from flooding & $\begin{array}{l}\text { Implement just the specific institutional projects already } \\
\text { foreseen and given as "certain" because they are already } \\
\text { funded or assigned to a builder (according to our collection } \\
\text { of existing proposals). }\end{array}$ \\
\hline
\end{tabular}

Note: this is a very important alternative because it is used as a reference to compare all others.

(3) ALT_SUDS (Sustainable Urban

Drainage Systems)

Safe city.

town harmonized with its environment.
Resolve the flood problem in the most effective way;

disturb as little as possible the population and urban POT, the land use and urbanization plan).

Reduce risk and maximize resilience; at the same time, recover and enhance the environment and the aesthetic-amenity-recreational value.
Apply SUDS criteria as far as possible

Conserve and recover the natural pathways of urban Cainage and temporary storage; adapt the urban fabric to the flood phenomenon; take advantage of the valuable environmental assets (wetlands, river).

Note: Basically, this alternative integrates the criteria of urban river restoration, SUDS and environmentally sustainable urban design, by minimizing the artificial infrastructures, while possibly greatly interfering in the status quo (e.g., by delocalization).

\begin{tabular}{|c|c|c|c|}
\hline (5) & ALT_MAX & A really safe city. & Reduce risk and take advantage of environmental assets. \\
\hline Note & This alternative plays $t$ & und. & \\
\hline (6) & ALT_R (Realistic) ([1]) & $\begin{array}{l}\text { A town harmonized with its environmental assets, } \\
\text { adapted to ensure a safe and comfortable life to its } \\
\text { citizens and guarantee a resilient future. }\end{array}$ & $\begin{array}{l}\text { Reduce risk and maximize resilience, while recovering } \\
\text { and enhancing the environment and the } \\
\text { aesthetic-amenity-recreational value. }\end{array}$ \\
\hline
\end{tabular}

Put into place all the means available with no care for costs.

(6) ALT_R (Realistic) ([1]) citizens and guarantee a resilient future.

Conserve and recover the natural pathways of urban drainage and temporary storage; take advantage of the valuable environmental assets (wetlands, river); establ

Tovember 2011), but perform well enough (i.e., be robust) also for the extreme event considered (T100CC).

Note: Actually, a number of different sub-variants $R 1, R 2, R 3$ of this ALT have been progressively set up, following the participatory process; but differences amongst them were marginal and did not deserve the creation of a new category. In what follows we refer to them globally again as $A L T \_R$ and specifically as " $R{ }_{-}, R_{-}{ }_{2}, R_{-} 3$ " when there is need to distinguish, or just with "ALT_R" in general.

(7) ALT_VIVIENDAS (“housing”)

A safe city (in relation to the reference event), without modifying current hydraulic setting and limiting the urban development foreseen in the POT.
Reduce risk; minimize intervention costs; disturb as little as possible current urban and hydraulic configuration and avoid to increase residual risk.
Eliminate vulnerability by adapting all houses affected by the reference event (T10); do not build works that would alter current hydraulic setuing or that may fail in the future; 


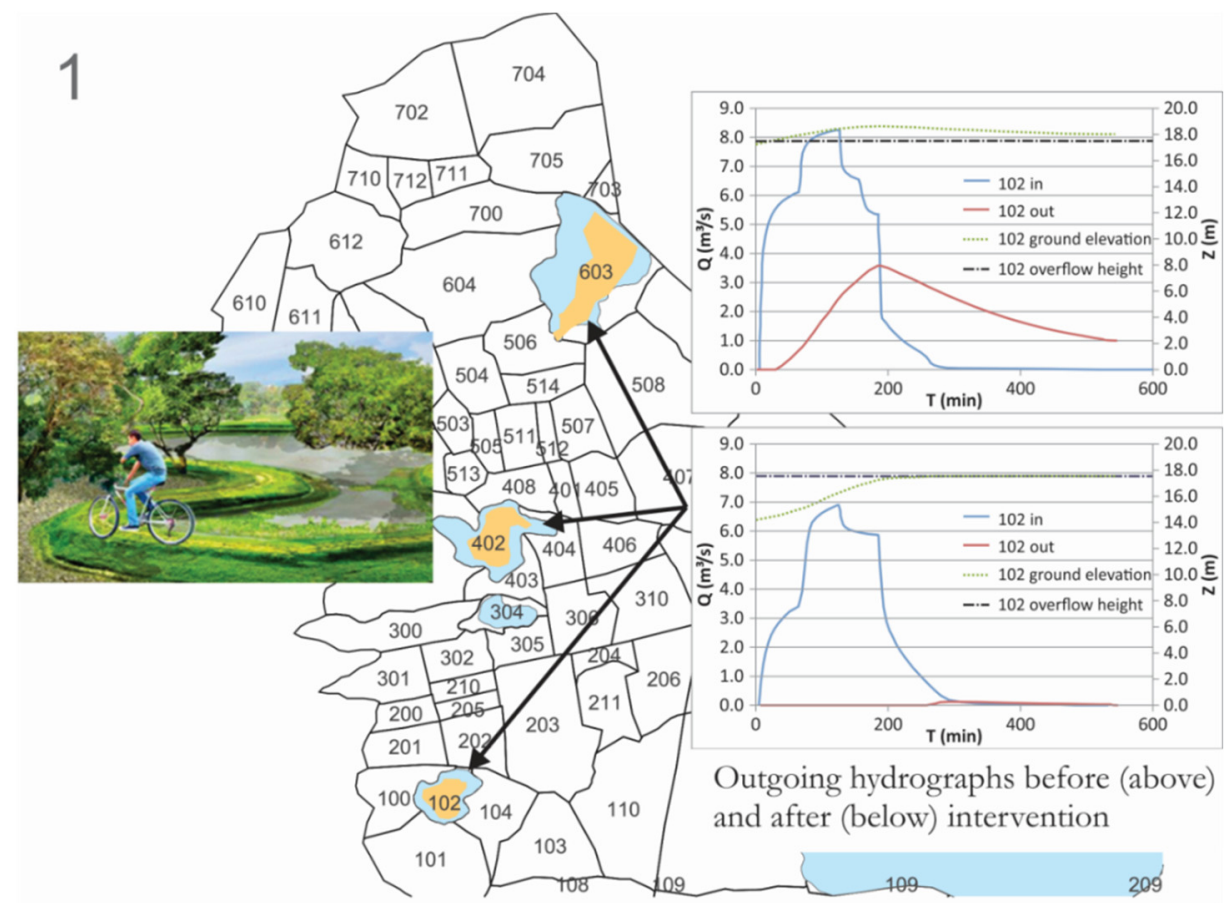

Enhance the buffering function of the humedales, while environmentally recovering them: morphological modification (depth, area) and outlet optimization (spillway)

Figure 14. Main solution options of ALT_R (see Table 1): enhancing wetlands ("humedales") functions.

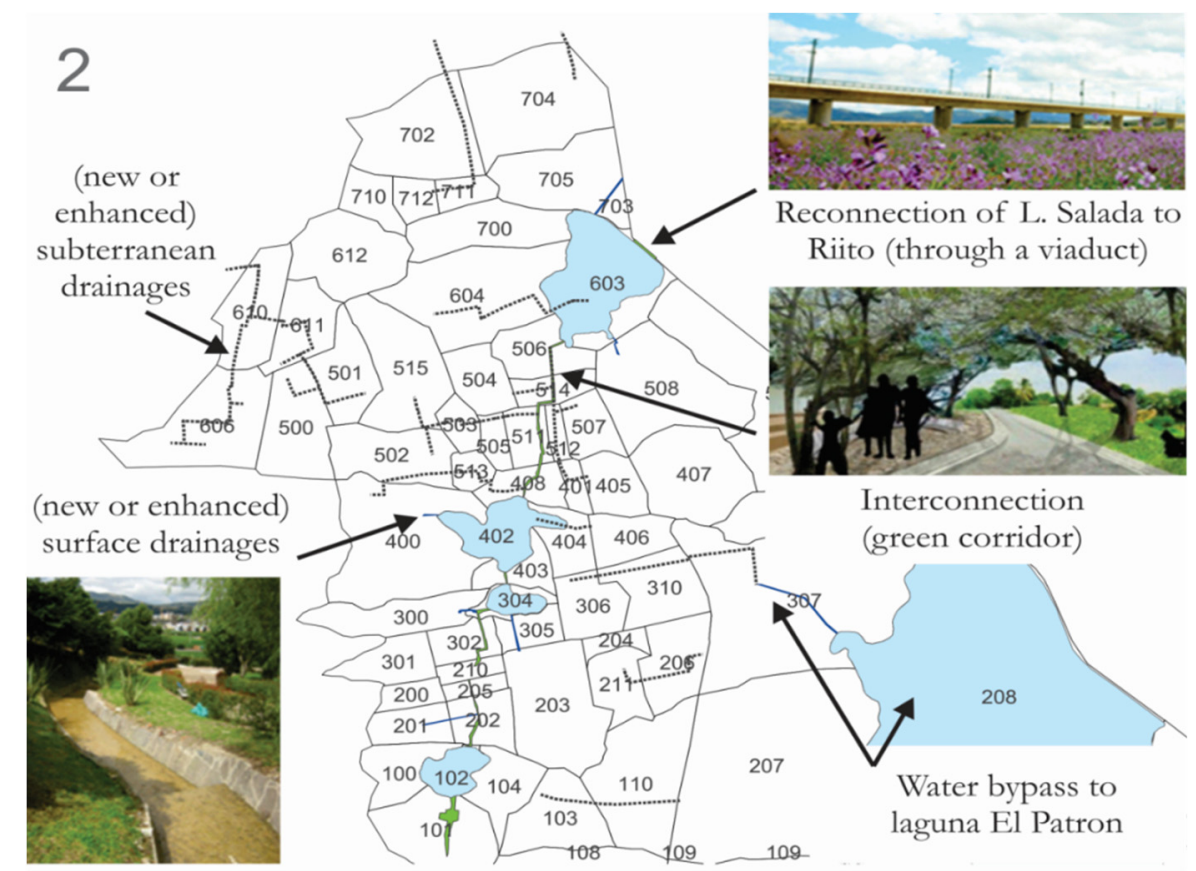

Recover the natural thalweg (greeen corridor); improve system drainage taking advantage of the multiple existing natural outlets

Figure 15. Main solution options of ALT_R: recover of the natural thalweg and system discharges. 


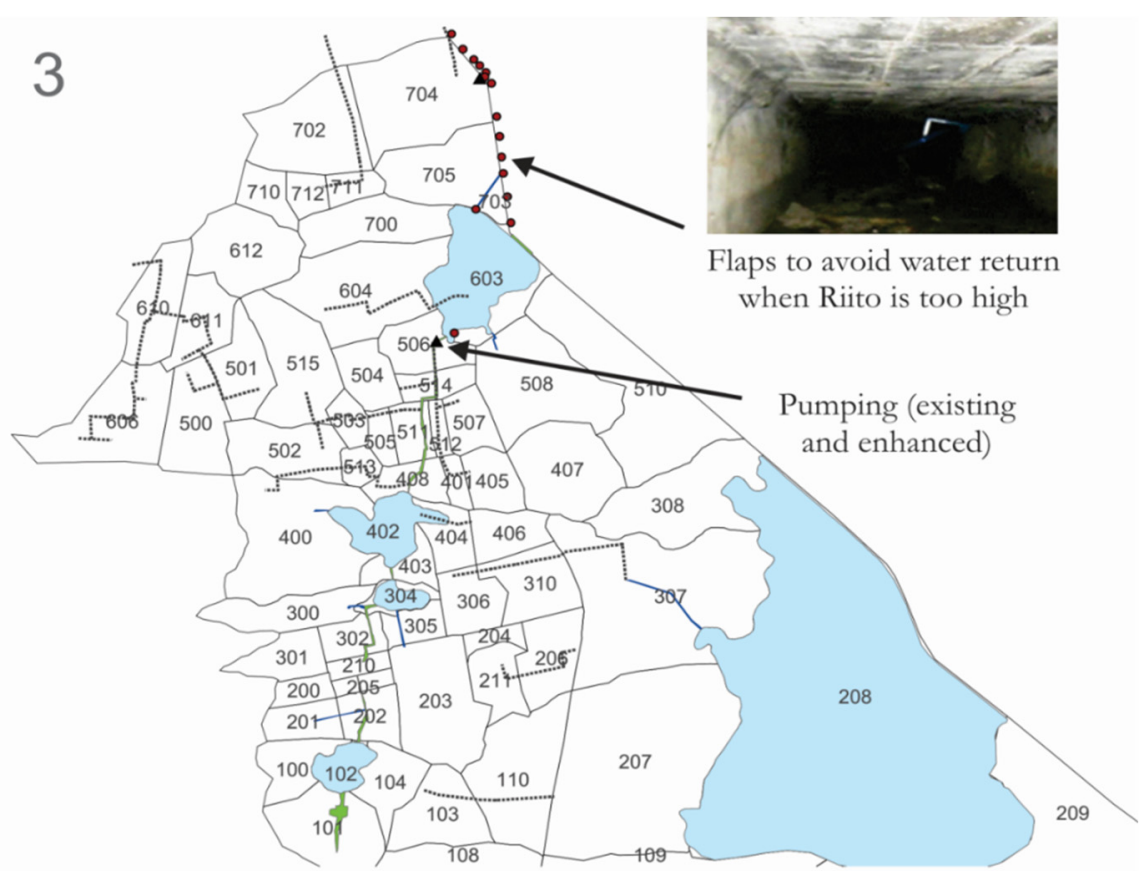

Improve the artificial drainage while protecting against extreme events with low urban rainfall and high river floods $\rightarrow$ pumping and flaps

Figure 16. Main solution options of ALT_R: drainage system improvement.

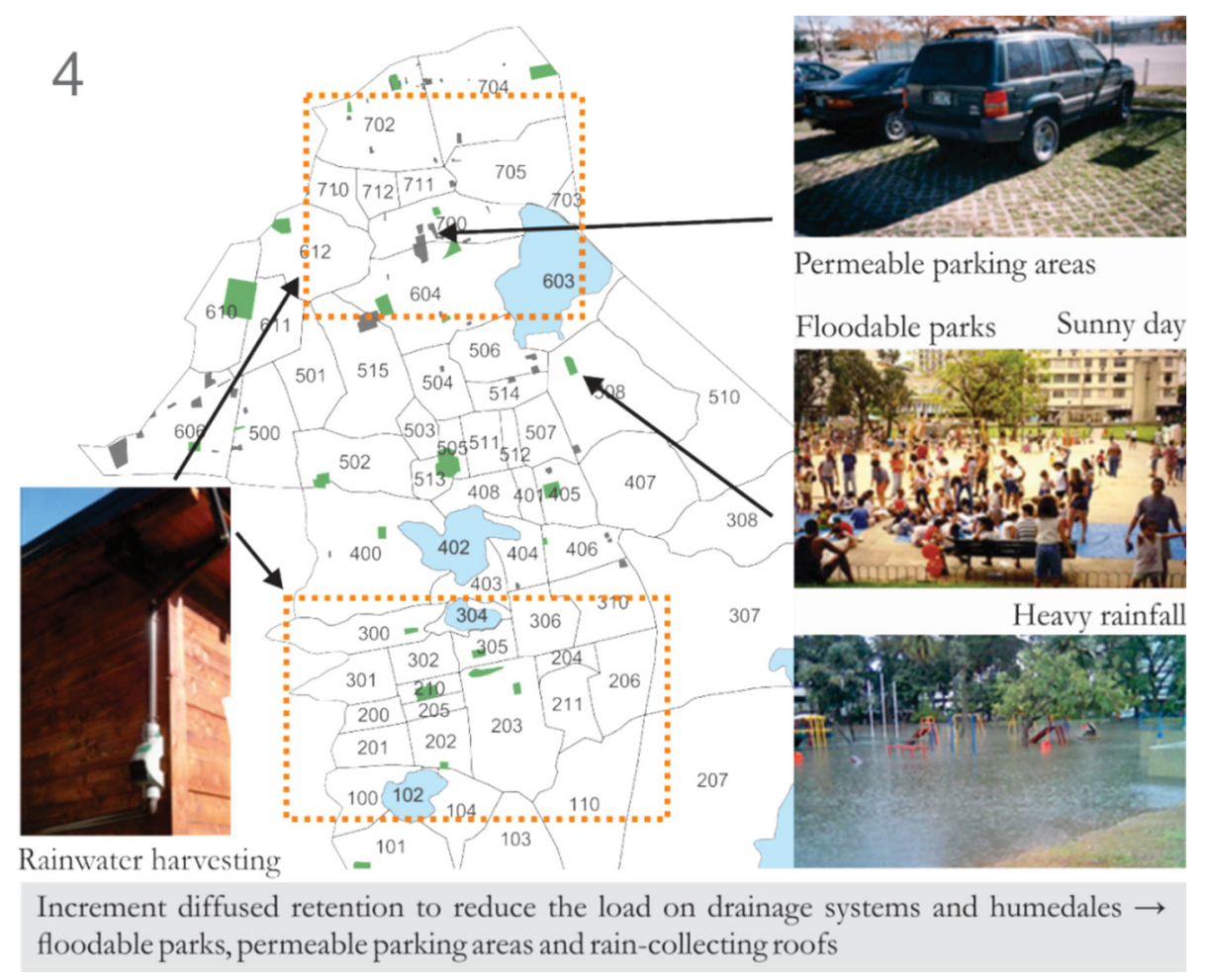

Figure 17. Main solution options of ALT_R: on-site control and multifunctional landscapes.

Another very important solution option that has not been represented in the previous maps (shown in Figures 14-17) is described here: land-use zoning. Three classes of land uses were proposed in floodable areas: 
(1) Adaptation zones-where existing houses have to be adapted to face harsher hydrological events with no or much less damages. It is determined by merging:

- $\quad f l o o d a b l e ~ z o n e s$ with T10 for ALT_R: although the philosophy is to establish safety against a T10 event, it is not ensured that no floodable zones remain; it is there that adaptation is most needed.

- topographic low zones with affected houses: local low zones that naturally tend to be flooded due to rainfall where some houses have already been affected (there may be other low zones where no damages have been reported because local natural or artificial drainages do work). Such zones are determined through a GIS operation on the DTM (hydrological analysis and intersection with the shapefile of affected houses, identified in the inquiry).

(2) Non-urbanization zones-where further urbanization has to be prevented. These are determined by merging:

- floodable zones with T100CC for ALT_R: it is always possible that an event harsher than the design occurs; thus, it does not make sense to increase the exposed values where such an events would flood.

- floodable zones with T100CC for ALT_Base: this measure would not make sense if the solution ALT_R is implemented; however, moving from current situation to the planned ALT_R will take years if not decades and during all this time the risk will remain and it would be wrong to increase it. Such zones will be freed only after ALT_R is fully implemented. It is a precautionary measure.

- topographic low zones: it would be unwise to foster urbanization there (only suitable constructions can be allowed, like those on piles).

(3) Delocalization zones-houses present in these zones have to be removed, and then reconstructed elsewhere in safe zones. These delocalization zones are determined by merging all zones where structural interventions incompatible with the presence of houses are foreseen within the solution ALT_R. In particular:

- morphological modification of wetlands;

- re-connection of wetlands (green corridor);

- (some of the) floodable parks; and

- $\quad$ surface drainage system.

Finally, it is important to stress that all this is to be accompanied by strong efforts to inform and empower the community to increase governance quality. These aspects are not described here, not because they are less important, but because their effects have not been explicitly considered in the cause-effect relationships (while they eventually should be, but at least they are not ignored).

\subsection{Synthesizing the Evaluation: Cases, Effect Table and Evaluation Matrix}

Several combinations ("cases") of "scenarios" and "alternatives" were considered in order to produce the relevant information for decision-making (see Supplementary Material). A first group of three cases $(1,2$, and 3 ) was set up just to investigate how the current system ("ALT_0") would react given either climate change or further urbanization, discovering that in this particular case, climate change would lead to the most relevant effects (once the urban area is already consolidated, the added stress caused by climate change would be more significant). The second group concerns the comparative evaluation of the ALTs. Notice that each case actually involves three simulations, according to the three possible events considered (the design one, corresponding to T10, i.e., a 10-year return period event, equivalent to the historical one of November 2011; T84, corresponding to the 
September 2011 historical event; and T100CC, the harshest event considered, referring to a return period of 100 years with climate change), together with their corresponding boundary conditions.

According to the evaluation framework established (see Supplementary Material, and Tables S1 and S3), the following effect table (Table 2) was obtained.

Table 2. Effect table and evaluation matrix for the flood planning problem addressed in Riohacha

(Notice that $R \_1, R \_2$, and $R \_3$ are just three variants of the ALT_R presented previously.).

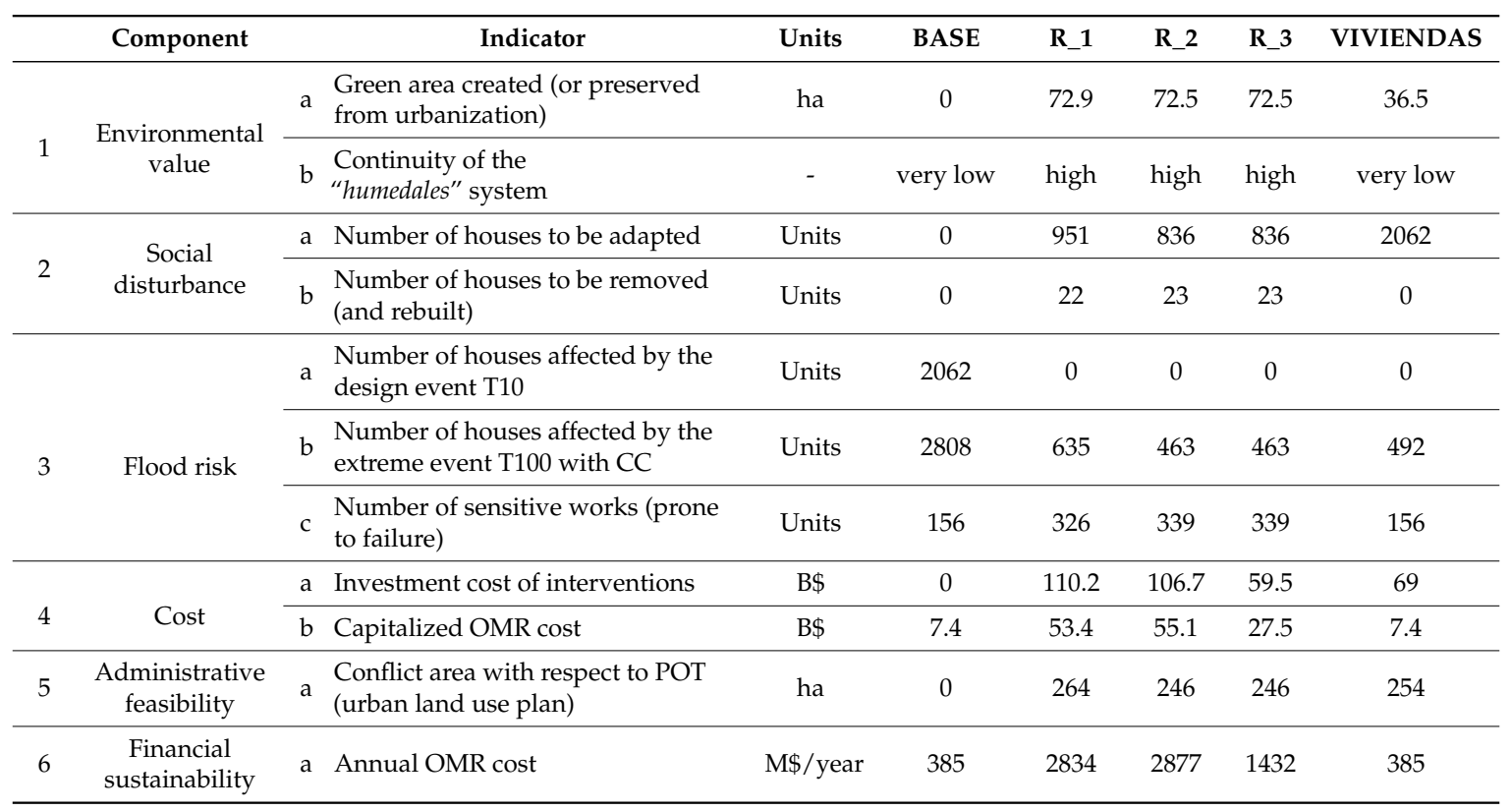

Note: all costs in Colombian pesos $\$$, where $1000 \mathrm{M} \$$ is approximately US\$ 400,000.

We now present a brief explanation of how the effects were computed:

- Environmental value: on the one hand, a holistic, subjective judgment is given concerning the continuity of the natural hydraulic system. On the other hand, the net green area created by the considered alternative, with respect to ALT_Base, is determined. This requires the following GIS: (i) create the potential new green area with a "merge" function between the solution option shapefiles for green corridors, morphological modification of "humedales", interconnection of "humedales", and floodable parks; (ii) erase the zones already green (as identified from a supervised classification of the satellite image available); (iii) merge the zones that will not experience urbanization, given the no-urbanization measure (a land-use constraint), minus those zones already urbanized; and (iv) erase from the resulting zones those in which just adaptation of houses is foreseen (no removal), because those areas will not become green, but rather just resilient (while greening is assumed to be a natural consequence where removal occurs).

- Risk: the fragility (proxy for residual risk) is simply determined by counting the artificial works related to flood control (assuming that $100 \mathrm{~m}$ of a linear structure counts as one work). The number of affected houses is simply determined by applying the scheme already presented in Figure 13.

- Disturbance: it is the number of houses to be removed (only the existing ones falling in removal zones) and the number of those to be adapted (existing ones falling in adaptation zones).

- Feasibility: this is the area where the POT (land use and urbanization plan) has to be modified, determined as the intersection between the urbanizable area according to the POT and the no-urbanization area from the shapefile of the corresponding measure.

- Cost and financial sustainability: a parametric, unit estimation of construction and Operation and Management (OM) costs was previously estimated for each solution option; so that for each alternative, we just multiplied and summed the magnitudes (areas, lengths, number,etc.) of the 
corresponding option times the corresponding unit costs. Additionally, a specific estimate of Replacement costs $(\mathrm{R})$ was carried out considering the typical expected life of each option and assuming that after each such period, a reconstruction cost will be incurred, although weighted by the adopted discount factor raised to the corresponding time index, during the planning interval of 50 years. The (un)sustainability is hence expressed as the OMR capitalized cost, reconverted into constant annuities.

Notice that only some alternatives are reported in this matrix; namely, those that were actually considered relevant in the evaluation, while all the others, although evaluated, were basically used as intermediate products to support the conception of the more attractive R-type alternatives.

By analyzing this effect matrix, the following considerations can be made:

- The business-as-usual (ALT_Base) alternative is indeed not acceptable because of the high number of houses affected by flooding.

- None of the considered alternatives actually dominates any other, as there always is at least one criterion under which another alternative is preferable.

- $\quad$ ALT_VIVIENDAS seems quite interesting since it is almost equivalent to the $\mathrm{R}$ alternatives, and even slightly better from a stand point of risk because it establishes safe conditions against a T10 event, is just slightly less robust for T100, but less fragile (fewer elements sensitive to failure). It costs slightly less than R3 overall and implies much lower OMR costs. However, its disturbance is high because it requires adapting a large number of houses. It also performs decidedly worse environmentally since it does not recover the hydraulic continuity of the system of wetlands and brings just half the new green area (thanks to avoided urbanization) compared to the $\mathrm{R}$ alternatives.

ALT_R3 was introduced only after a first evaluation session of this type and after the simplified cost-benefit analysis, reported further below. It substantially coincides with the R2, but is optimized economically. More precisely, it foresees the same interventions, except those that are hydraulically less efficient and quite costly (according to the unit parametric estimates carried out), which in our case are as follows:

- $\quad$ the permeable parking areas; and

- the rainfall gathering roofs (and associated tanks).

Furthermore, it foresees a much shorter (only $50 \mathrm{~m}$ long) viaduct to reconnect Laguna Salada and Riito, which we proved to be hydraulically equivalent.

\subsection{Relative Importance Judgments and Choice}

Developing further considerations and particularly reaching a preferential ranking of the alternatives is quite cumbersome with such information because for some indices better situations correspond to higher values, while for others the reverse holds (furthermore, in general, for a given increment in numerical value the same increment in satisfaction does not necessarily follow).

To overcome these difficulties, the evaluation matrix shown in Table 3 was introduced, where for each macro-criterion a synthetic index was adopted. These indices were normalized between 1 (best) and 0 (worst), corresponding to the extreme values reported in Table 2. This transformation was obtained by applying to each group of indicators corresponding to a macro-criterion (component) a simple multi-attribute additive value function with linear scalar value functions [43,44].

The subjective values were elicited in a meeting between the CREACUA analyst and the representative of the municipal government. First, the meaning of the evaluation attributes in general was clarified; then, the meaning of the extreme values of each one was exemplified. Hence, the public officer was invited to indicate, for each group of sub-attributes, the most important within that group and, additionally, an importance score (for each $\mathrm{k}$ belonging to group i) on a scale 1-5 
was assigned ( 5 being the most important). This is one of the simplest methods to elicit preferences (see, for instance, Janssen [45] for further details). With that information, the internal weights were computed as: $\mathrm{w}_{\mathrm{ik}}=\mathrm{p}_{\mathrm{ik}} /\left(\Sigma \mathrm{k} \mathrm{p}_{\mathrm{ik}}\right)$. In a similar and even simpler fashion, the seven key objectives were ranked, producing the rank value $r_{j}$ and, with this, the relative weights to be used in the multicriteria evaluation, determined as: $w_{j}=\left(7-r_{j}\right) /\left(\Sigma_{j} r_{j}\right)$.

Table 3. Evaluation matrix for the flood planning problem addressed in Riohacha.

\begin{tabular}{ccccccccc}
\hline No. & Component & Priority & Weight & BASE & REAL_1 & REAL_2 & REAL_3 & VIVIENDAS \\
\hline 1 & Environmental value & 2 & 0.238 & 0 & 0.99 & 0.99 & 0.99 & 0.18 \\
2 & Social disturbance & 3 & 0.19 & 1 & 0.46 & 0.5 & 0.5 & 0.14 \\
3 & Flood risk & 1 & 0.286 & 0.28 & 0.83 & 0.84 & 0.84 & 0.9 \\
4 & Cost & 5 & 0.095 & 0.97 & 0.31 & 0.33 & 0.64 & 0.68 \\
5 & Administrative feasibility & 6 & 0.048 & 1 & 0.12 & 0.18 & 0.18 & 0.15 \\
6 & Financial sustainability & 4 & 0.143 & 0.87 & 0.06 & 0.04 & 0.52 & 0.87 \\
& Weighted average & & & 0.54 & 0.6 & 0.62 & 0.71 & 0.53 \\
$\quad$ RANKING & & & 4 & 3 & 2 & 1 & 5 \\
\hline
\end{tabular}

The result of this step is reported in the evaluation matrix presented in Table 3:

The priorities elicited from the municipal government representatives are influenced by the following observations:

- the flood risk is indeed a significant problem that cannot be ignored;

- the town suffers from a limited presence of green areas and the abandonment of the wetlands system; and

- for the municipal government, the maintenance cost (OMR) is clearly more important than the investment cost because of the higher chance of covering a large portion of the latter through outside money (cooperation arrangements, governmental support, etc.), while the OMR cost has to be covered yearly through revenues that eventually the same municipal government has to ensure and disburse (endogenous resources).

The consequence of this elicitation of preferences is the ranking reported at the foot of the evaluation matrix shown in Table 3; that is, ALT_R3 is the winner.

However, it is reasonable to wonder whether this choice is justified economically. This point has been addressed with a simplified Cost-Benefit Analysis. In a straightforward CBA approach, first costs (C) and benefits (B) are assessed and then compared; then, if B exceeds $C$, the alternative is economically viable (and vice versa). However, as it is quite hard to assess the damage itself (and hence the benefit defined as risk reduction), we proceed inversely: we determine which value should assume the parameter "unit damage c" in order to cause a given alternative to have at least a zero cost-benefit balance. Thereafter, some reflections on the value found are carried out to discuss whether it makes sense or not, i.e., whether the c value would be proportioned to the actual type of houses encountered in the area, ensuring it is sufficiently realistic. The value $\mathrm{c}$ is hence a parameter to be determined.

Notice that the indicator "net social benefit" $\left(\mathrm{B}_{\mathrm{N}}\right)$, representing the "economic efficiency" is not included in the evaluation matrix, exactly because the actual damage value is not calculated; it rather plays an analytic role.

The conclusion from this simplified CBA is that:

- The economically most efficient alternative is "ALT_VIVIENDAS" (which does not foresee any hydraulic intervention and just adapts the affected houses and imposes a land use constraint for the future).

- In order to show a non-negative CBA balance of such an alternative, the parameter c must assume at least the value of $17.2 \mathrm{M} \$$ /house/event; this is a relatively high value, approximating half the average cost of full adaptation of a house in the same place, but does not seem to be that far from reality. 
- In order for the ALT_R3 to be viable (even if not the best one), the unit damage c must assume at least the value $19.9 \mathrm{M} \$$ /house/event, which is almost coincident with the ALT_VIVIENDAS' value.

This analysis would seem, strictly economically speaking, to lead to prefer ALT_VIVIENDAS, which is a different choice from that suggested by the multicriteria analysis already presented. However, it must not be forgotten that:

- This is a simplified evaluation because the damage in reality does depend on the hydraulic characteristics of the event and on the type of house.

- It does not consider the residual risk associated with the failure of works (which would add advantages with respect to the ALT_VIVIENDAS).

- It does not include the loss of land value because of land use development constraints (larger area for ALT_VIVIENDAS than others).

- The actual damage (and the risk) also includes the indirect and the intangible components (e.g., the disturbance and suffering associated with being flooded even if the house is adapted and is not susceptible to losses, including sickness and lost working days), and as such the benefit from "risk reduction" is certainly larger than the one estimated here.

- Moreover, the analysis does not include the benefit (associated with the R ALTs) of increasing the green corridor and improving the hydraulic continuity of the wetlands system.

- Furthermore, it does not consider the drawback associated with the disturbance to people because of adaptation of such a large number of houses (much larger for ALT_VIVIENDAS than for the other alternatives), which would certainly be a social issue and bring opposition.

In conclusion, selecting R3 amongst all the alternatives seems quite sensible from both the MCA point of view and that of an enlarged CBA.

The only real weak point of ALT_R3 is the high Operation, Maintenance and Replacement cost (OMR). A feasible strategy to control this could be to motivate the local community so that people themselves would take part in maintaining most of the infrastructure, reducing the need for municipal maintenance (basically by avoiding the improper disposal of garbage and other urban detritus).

Finally, it must be noted that the elimination from ALT_R3 of the least efficient interventions (rain collecting roofs and permeable parking areas) does not imply forgoing them. It just acknowledges that it is quite expensive to create them in an existing urban space, but it remains reasonable and recommendable to always include them in new urbanization areas (i.e., they should be included in the future urban master plan).

\section{Conclusions and Lessons Learnt}

Concerning the overall results of the project and its outcomes, we reached a very integrated action plan, well shared with both the local community and the different (and not always communicating) entities in terms of decision-making process and of technical choices.

The conclusions from the project have already been incorporated in the new Land Use Plan proposal now submitted to political approval (the concept of hydraulic invariance, no-build zoning, introduction of specific SUDS concepts, etc.) and have drawn the interest of several institutional and international subjects to get implemented. The mutual communication and confidence amongst the involved institutions has definitely increased thanks to the project.

It is interesting to note that the benefit of risk reduction alone might not justify the envisioned set of interventions, but when environmental and social aspects are included, the plan is in general well justified. This result, and indeed the whole process, has been strongly driven by the integrated evaluation approach, without which probably a different (and more questionable) decision would have been made. 
It is also interesting to note how international cooperation is likely to distort public decision making, as the weight given to investments is strongly reduced, possibly causing an economically inefficient choice to be made.

Concerning the technicalities of the project, the MODCEL simulation model performed quite well and proved to be an essential ingredient. Without it, no one could have understood which interventions were actually effective or not and it is very likely that their effectiveness would have been overestimated, leading to false security.

The time-consuming structured inquiry (and associated ACCESS Database) was indispensable and we recommend carrying out similar exercises for future analogous projects, since it provided, on one side, essential knowledge on the system behavior (e.g., flow directions), and on the other the only objective data that allowed a scientific calibration and validation of the model.

The definition of MODCEL cells is a delicate, iterative process. There is no way to avoid modifications, since it is only through the preliminary simulations that an actual understanding of the system response to causal factors can be really assessed.

MODCEL is a conceptual model and, coherently, its results only indicate the equivalent flooded depth in each cell; however, it is essential to translate such outputs in terms of the geographic reality (zones effectively flooded), because only at that level can the number of houses and other elements affected by a flooding be meaningfully assessed and as such the damages be computed and understood.

MODCEL offers an important advantage with respect to other more physically based models: a conventional topography is sufficient and the modeler is indeed "forced" to compensate for the lack of precise knowledge of some details by deeply understanding how the system works in reality, so identifying the key elements to be considered in terms of solutions. Of course, some refinements of topography may be required, but only very specific ones, with low cost. More advanced technology, like LIDAR surveys, can of course be useful, but probably they will never fill the gap between real system and model.

From the social point of view, thanks to the participatory process and the tools set up to support it (an info point called "open house", an illustrative leaflet on right and wrong typical behaviors, a game to interiorize system and people's behaviors, etc.), the community perception has changed through the process both about the project in general and about specific solutions. On the one hand, the fact that suggestions proposed or developed in some meetings were indeed included in the plan, and that there were solid arguments not to espouse other proposals (e.g., to see a new drainage systems as "the solution"), increased the trust in the project team and results. On the other, the typical ineffectiveness of government agents' promises, that had previously generated disillusion and lack of will to participate, has been slowly overcome; but it is now up to the new municipal government not to betray this renewed trust.

We think that the approach presented here benefits from a balanced mix of the two key components that should pervade any decision process in the environmental area: public participation and technical-scientific analysis and know-how. Too often cooperation agencies and officers come to Latin American countries with pre-established action patterns and without sufficient knowledge and awareness of the reality, exceeding one of the two components.

On the negative side is the heaviness of the process because of the highly participatory nature (which required many meetings, interruptions in the development to wait for the next meeting, and several associated revisions of the work) and because of the multiple alternative solutions considered: while with a traditional engineering approach the design team would have developed just "one project", here several projects were developed in parallel and iteratively. Modifying small (or big) details in a project based on a systemic view and modeling requires redoing a lot of sequential steps (e.g., incorporating a new zone, because people reported a problematic situation previously unknown, requiring changing the modeled cells, and hence all the GIS shapefiles, the volume-elevation curves, the source files of the GIS flood tool, all the simulation with the associated impact indices, etc.). 
A basic requirement is to achieve a complete, updated, coherent and trustable topographic basis (elevation points or contour curves), even if not particularly detailed ( $50 \mathrm{~cm}$ spacing may be sufficient for most cases). We are currently exploring the benefits of adopting LIDAR technology.

Another weak point of our project is the in-depth assessment of environmental consequences associated with the modification of the "humedales" and their connection (although we expect they will be mainly positive, mosquitoes, water-borne diseases and odor problems are possible). This issue deserves more specific and accurate analysis.

A full cost-benefit analysis would at least strengthen our conviction of having made a good choice.

A final important consideration is that this complex planning process has to be strictly geared to the political process of land use planning with an administration that is willing and able to act in its territory. Without this condition, any plan, even if perfectly rational and scientifically sound and even possibly "participatory", would remain just a plan, while illegal and unsuited urbanization will continue to spread.

Supplementary Materials: The following are available online at http://www.mdpi.com/2071-1050/8/3/198/s1, Figure S1: Computation of the probability of occurrence associated with an event with return period TR, Table S1: "Cases" (combination of a Scenario and an ALTernative) submitted to simulation, Table S2: Evaluation indicators adopted, Table S3: Relevant cause-effect relationships amongst solution options (columns, with vertical writings in the first row) and indicators (rows), Table S4: Calculation of direct, tangible risk, when the value of 19.9 $\mathrm{M}$ \$/house/event is given, Table S5: Cost-benefit calculations (given the $19.9 \mathrm{M} \$ \mathrm{col} /$ house/event of parameter c).

Acknowledgments: This research was possible thanks to funding from the UNGRD (Unidad Nacional de Gestión de Riesgo y Desastres de Colombia), through cooperation agreement no. 9677-04-1047-2013, the co-funding and information provided by the Riohacha municipal government, the support provided by students and professors of the Universidad de la Guajira (Riohacha, Colombia) and the invaluable technical assistance of COPPETEC staff from UFRJ (Rio de Janeiro, Brazil). The UNGRD is a governmental body which issued a call for innovative proposals for the management of flood risk after the "ola invernal 2010-2011" event, which deeply affected a large portion of the country; the Colombian Fundación CREACUA of Riohacha was amongst the three winners at the national level, with a project proposal to address the flood problem, and conducted the whole study. The material presented here is derived from that experience.

Author Contributions: Andrea conceived and conducted the whole project and hence set up the main structure of the paper and wrote the basis of all sections including that concerning evaluation. Marcelo introduced the SUDS concept and was in charge of MODCEL modeling and as such he wrote the section on urban flooding philosophy, developed the discussion on the suitability of MODCEL and generated the relevant information from MODCEL application. Both contributed to reply to the demanding, but very useful comments from reviewers.

Conflicts of Interest: The authors declare no conflict of interest.

\section{References}

1. Banco Interamericano de Desarrollo (BID). Valoración de daños y pérdidas. Ola invernal en Colombia 2010-2011; Comisión Económica para América Latina y el Caribe (CEPAL): Bogotá, Colombi, 2012. (In Spanish)

2. Intergovernmental Panel on Climate Change (IPCC). The Fourth Assessment Report of the Intergovernmental Panel on Climate Change; Solomon, S., Qin, D., Manning, M., Chen, Z., Marquis, M., Averyt, K.B., Tignor, M., Miller, H.L., Eds.; Cambridge University Press: Cambridge, UK, 2007.

3. Instituto de Investigaciones Marinas y Costeras (INVEMAR). Programa Holandés de asistencia para estudios en Cambio Climático: Colombia. Definición de la vulnerabilidad de los sistemas bio-geofisicos y socioeconómicos debido a un cambio en el nivel del mar en la zona costera colombiana (Caribe, Insular y Pacifica) y medidas para su adaptación. Available online: http://www.eco-index. org/search/pdfs/colombia.pdf (accessed on 18 February 2016). (In Spanish)

4. Instituto de Hidrología, Meteorología y Estudios Ambientales (IDEAM). Vulnerabilidad y adaptación de la zona costera colombiana al ascenso acelerado del nivel del mar. Available online: http://www.ops. org.bo/textocompleto/iam21406.pdf (accessed on 18 February 2016). (In Spanish)

5. Comisión Económica para América Latina y el Caribe (CEPAL). Estudio regional de los efectos del cambio climático en la costa de América Latina y el Caribe (ALyC). Available online: http://www.lariocc.es/es / reuniones-documentos/reuniones/2._RESUMEN_PROYECTO_COSTAS_ALYC_UC_tcm25-224239.pdf (accessed on 18 February 2016). (In Spanish) 
6. Ministerio de Ambiente y Desarrollo Sostenible. Estrategia Colombiana de Desarrollo Bajo en Carbono. Available online: https://www.minambiente.gov.co/index.php/component/content/article/469-plantillacambio-climatico-25\#documentos (accessed on 8 January 2016). (In Spanish)

7. Miguez, M.G.; Mascarenhas, F.C.B.; Magalhães, L.P.C. Multifunctional landscapes for urban flood control in developing countries. Int. J. Sustain. Dev. Plan. 2007, 2, 153-166. [CrossRef]

8. Walsh, T.; Pomeroy, C. Decentralization of LID (e.g. Municipal Rainwater Harvesting Program) for Reducing Stormwater Runoff. In Proceedings of the World Environmental and Water Resources Congress 2012: Crossing Boundaries, Albuquerque, NM, USA, 20-24 May 2012.

9. Fassman, E.A.; Blackbourn, S. Urban runoff mitigation by a permeable pavement system over impermeable soils. J. Hydrol. Eng. 2010, 15, 475-485. [CrossRef]

10. Gregoire, B.G.; Clausen, J.C. Effect of a modular extensive green roof on stormwater runoff and water quality. Ecol. Eng. 2011, 37, 963-969. [CrossRef]

11. Ahiablame, L.M.; Engel, B.A.; Chaubey, I. Effectiveness of Low Impact Development Practices: Literature Review and Suggestions for Future Research. Water Air Soil Pollut. 2012, 223, 4253-4273. [CrossRef]

12. Miguez, M.G.; Bahiense, J.M.; Rezende, O.M.; Veról, A.P. Sustainable Urban Drainage Approach, Focusing on LID Techniques, Applied to the Design of New Housing Subdivisions in the Context of a Growing City. Int. J. Sustain. Dev. Plan. 2014, 9, 538-552. [CrossRef]

13. Binder, W. Restoration of rivers and floodplains in Bavaria. In Proceedings of the 3rd European Conference on River Restoration, Zagreb, Croatia, 17-21 May 2004.

14. Centro Italiano per la Riqualificazione Fluviale (CIRF). La riqualificazione fluviale in Italia: linee guida, strumenti ed esperienze per gestire i corsi d'a cqua e il territorio, 1st ed.; Nardini, A., Sansoni, G., Eds.; Mazzanti: Venezia, Italy, 2006. (In Italian)

15. Dufour, S.E.; Piégay, H. From the Myth of a Lost Paradise to Targeted River Restoration: Forget Natural References and Focus on Human Benefits. River Resear. Appl. 2009, 25, 568-581. [CrossRef]

16. González Del Tánago, M.; García De Jalón, D. Restauración de ríos. Guía metodológica para la elaboración de proyectos; Ministerio de Medio Ambiente: Madrid, Spain, 2007. (In Spanish)

17. Gusmaroli, G.; Bizzi, S.; Lafratta, R. L'approccio della Riqualificazione Fluviale in Ambito Urbano: Esperienze e Opportunittà. In Proceedings of the $4^{\circ}$ Convegno Nazionale di Idraulica Urbana, Venezia, Italy, 21-24 June 2011. (In Italian)

18. Leummens, H.; Menke, U. ECRR Addressing Practitioners; Every Child Ready to Read (ECRR) Productions: Lelystad, The Netherlands, 2008.

19. Kibel, P.S. Rivertown: Rethinking Urban Rivers; MIT Press: Cambridge, MA, USA, 2007.

20. Mascarenhas, F.C.B.; Miguez, M.G. Urban flood control through a mathematical flow cell model. Water Int. 2002, 27, 208-218. [CrossRef]

21. Mascarenhas, F.C.B.; Toda, K.; Miguez, M.G.; Inoue, K. Flood Risk Simulation; Wessex Institute (WIT): Southampton, UK, 2005.

22. Lasage, R.; Muis, S.; Sardella, C.; van Drunen, M.A.; Verburg, P.H.; Aerts, J.C.J.H. A stepwise, Participatory Approach to Design and Implement Community Based Adaptation to Droughts in the Peruvian Andes. Sustainability 2015, 7, 1742-1773. [CrossRef]

23. Andoh, R.Y.G.; Iwugo, K.O. Sustainable Urban Drainage Systems: A UK Perspective. In Proceedings of the 9th International Conference on Urban Drainage, Portland, OR, USA, 4-6 September 2002.

24. United States Environmental Protection Agency (USEPA). The Use of Best Management Practices (BMPS) in Urban Watersheds; Muthukrishnan, S., Madge, B., Selvakumar, A., Field, R., Sullivan, D., Eds.; Office of Research and Development: Washington, DC, USA, 2004.

25. Elliott, A.H.; Trowsdale, S.A. A review of models for low impact urban stormwater drainage. Environ.l Model. Software 2007, 22, 394-405. [CrossRef]

26. Coffman, L.S.; Cheng, M.; Weinstein, N.; Clar, M. Low-Impact Development Hydrologic Analysis and Design; American Society of Civil Engineers (ASCE): Chicago, IL, USA, 1998.

27. Woods-Ballard, B.; Kellagher, R.; Martin, P.; Bray, R.; Shaffer, P. The SUDS Manual; Construction Industry Research and Information Association (CIRIA) C697; CIRIA: London, UK, 2007.

28. Argue, J.R. WSUD: Basic Procedures for 'Source Control' of Stormwater-A Handbook for Australian Practice. Available online: http://www.waterbucket.ca/rm/sites/wbcrm/documents/media/55.pdf (accessed on 18 February 2016). 
29. Melbourne Water. WSUD Engineering Procedures: Stormwater; Commonwealth Scientific And Industrial Research Organisation (CSIRO) Publishing: Collingwood, Australia, 2005.

30. Coombes, P.J.; Argue, J.R.; Kuczera, G. Figtree Place: A Case Study in Water Sensitive Urban Development (WSUD). Urban Water 1999, 1, 335-343. [CrossRef]

31. Fletcher, T.D.; Shuster, W.; Hunt, W.F.; Ashley, R.; Butler, D.; Arthur, S.; Trowsdale, S.; Barraud, S.; Semadeni-Davies, A.; Bertrand-Krajewski, J.; et al. SUDS, LID, BMPs, WSUD and more-The evolution and application of terminology surrounding urban drainage. Urban Water J. 2014. [CrossRef]

32. Miguez, M.G.; Rezende, O.M.; Veról, A.P. City Growth and Urban Drainage Alternatives: Sustainability Challenge. J. Urban Plan. Dev. 2014, 140, 04014026.

33. Miguez, M.G.; Mascarenhas, F.C.B.; Magalhães, L.P.C.; D'Alterio, C.F.V. Planning and Design of Urban Flood Control Measures: Assessing Effects Combination. J. Urban Plan. Dev. 2009, 135, 100-109. [CrossRef]

34. Zanobetti, D.; Lorgeré, H. Le Modele Mathématique du Delta du Mékong. La Houille Blanche 1968. [CrossRef]

35. Abily, M.; Duluc, C.M.; Faes, J.B.; Gourbesville, P. Performance assessment of modelling tools for high resolution runoff simulation over an industrial site. J. Hydroinform. 2013, 15, 1296-1311. [CrossRef]

36. DHI. DHI models. Available online: https://www.dhigroup.com/ (accessed on 29 January 2016).

37. Crowder, R.A.; Pepper, A.T.; Whitlow, C.; Sleigh, A.; Wright, N.; Tomlin, C. Benchmarking of Hydraulic River Modelling Software Packages; Environment Agency: Bristol, UK, 2004.

38. Néelz, S.; Pender, G. Benchmarking of 2D Hydraulic Modelling Packages; Environment Agency: Bristol, UK, 2010.

39. Mignot, E.; Paquier, A.; Haider, S. Modeling floods in a dense urban area using $2 \mathrm{~d}$ shallow water equations. J. Hydrol. 2006, 327, 186-199. [CrossRef]

40. Neal, J.; Bates, P.; Fewtrell, T.; Hunter, N.M.; Wilson, M.; Horritt, M. Distributed whole city water level measurements from the Carlisle 2005 urban flood event and comparison with hydraulic model simulations. J. Hydrol. 2009, 368, 42-55. [CrossRef]

41. Neal, J.; Villanueva, I.; Wright, N.; Willis, T.; Fewtrell, T.; Bates, P. How much physical complexity is needed to model flood inundation? Hydrol. Process. 2012, 26, 2264-2282. [CrossRef]

42. CENTRO DE RECUPERACIÓN DE ECOSISTEMAS ACUÁTICOS (CREACUA). Proyecto: “Adaptación Urbana Verde frente a inundaciones con el soporte de la modelación matemática y del software MODCEL en Riohacha, La Guajira, Colombia"; Convenio de cooperación No 9677-04-1047-2013; CREACUA: Riohacha, Colombia, 2015. (In Spanish)

43. Nardini, A. A Systematic Approach to Build Evaluation Indices for Environmental Decision Making with Active Public Involvement. Rivista di Economia delle fonti di Energia e dell' Ambiente 2003, 46, 189-215.

44. Beinat, E. Multiattribute Value Functions for Environmental Management; Springer Netherlands: Amsterdam, The Netherlands, 1995.

45. Janssen, R. Multiobjective Decision Support for Environmental Management; Springer Netherlands: Amsterdam, The Netherlands, 1992.

(C) 2016 by the authors; licensee MDPI, Basel, Switzerland. This article is an open access article distributed under the terms and conditions of the Creative Commons by Attribution (CC-BY) license (http:/ / creativecommons.org/licenses/by/4.0/). 